Florida International University FIU Digital Commons

\title{
The non-timber forest products sector in nepal: policy issues in plant conservation and utilization
}

Ranju Shresthal Acharya

Florida International University

DOI: $10.25148 /$ etd.FI13101519

Follow this and additional works at: https://digitalcommons.fiu.edu/etd

Part of the Environmental Sciences Commons

\section{Recommended Citation}

Acharya, Ranju Shresthal, "The non-timber forest products sector in nepal : policy issues in plant conservation and utilization" (2007). FIU Electronic Theses and Dissertations. 1085.

https://digitalcommons.fiu.edu/etd/1085 
Miami, Florida

THE NON-TIMBER FOREST PRODUCTS SECTOR IN NEPAL: POLICY ISSUES IN PLANT CONSERVATION AND UTILIZATION

A thesis submitted in partial fulfillment of the

requirements for the degree of

MASTER OF SCIENCE

in

ENVIRONMENTAL STUDIES

by

Ranju Shrestha Acharya 
To: Interim Dean Mark Szuchman

College of Arts and Sciences

This thesis, written by Ranju Shrestha Acharya, and entitled The Non-Timber Forest Products Sector in Nepal: Policy Issues in Plant Conservation and Utilization, having been approved in respect to style and intellectual content, is referred to you for judgment.

We have read this thesis and recommend that it be approved.

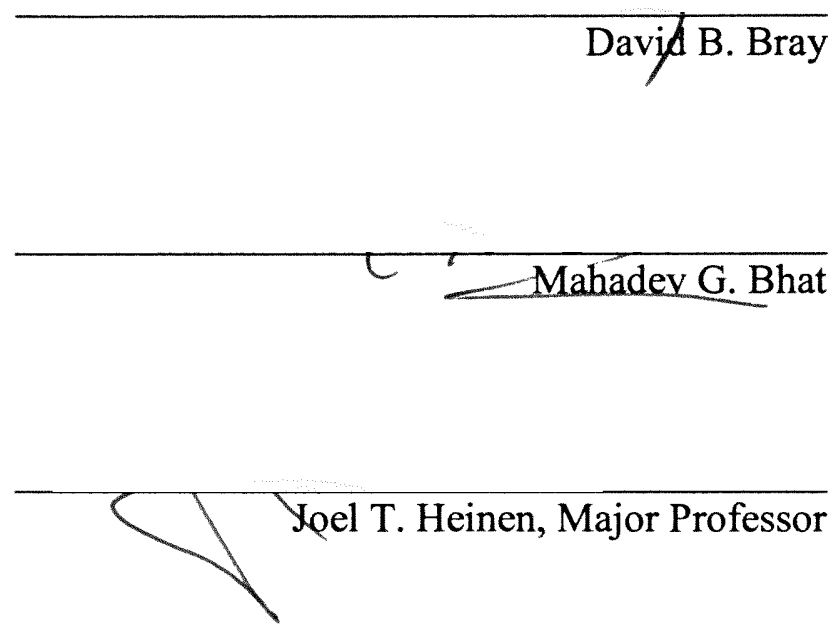

Date of Defense: May 16, 2007

The thesis of Ranju Shrestha Acharya is approved.

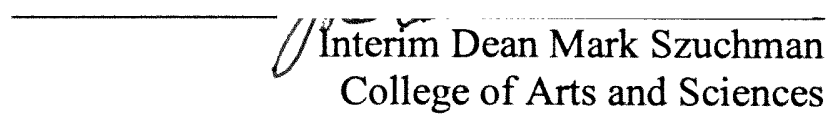

College of Arts and Sciences

(Dean George Walker University Graduate School

Florida International University, 2007 


\section{DEDICATION}

I dedicate this thesis to all who are working for the development and bright future of my country Nepal. 


\section{ACKNOWLEDGMENTS}

First I would like to extend my sincere gratitude to my major professor, Dr. Joel T. Heinen, for his constant guidance and support all through my work. It is great to have a major professor like him. I would like to thank my committee member, Dr. David B. Bray, for his very constructive and thought provoking comments on my work from the very beginning. I would also like to thank my other committee member, Dr. Mahadev G. Bhat, for his constant support.

I am grateful to the Judith Parker Scholarship from the Department of Environmental Studies and Fu Foundation Scholarship from the Institute of Asian Studies at FIU for providing me with travel funds which enabled me to travel to Nepal to collect my data. All the interviewees in Nepal were very generous in sharing information during interviews and documents needed for my thesis without which this work would not have been possible. It was a very pleasant experience interacting with them and thanks are due to them. Thanks are due to my colleagues at the International Center for Integrated Mountain Development (ICIMOD) in Nepal, where I used to work before I came to FIU, for their support. Further, I would like to thank the friends at FIU for providing information whenever I needed, the professors in the Department of Environmental Studies for their encouragement and the department personnel for being helpful.

I am thankful to my husband, Parshuram Acharya, whose support, understanding, patience and sacrifice, made the completion of this work easier. I also owe a lot to my six years old daughter, Prachee, for being so understanding when her mother was busy at her work. I am grateful to my parents whose blessings are always with me. 


\title{
ABSTRACT OF THE THESIS
}

THE NON-TIMBER FOREST PRODUCTS SECTOR IN NEPAL: POLICY ISSUES IN PLANT CONSERVATION AND UTILIZATION

by

\author{
Ranju Shrestha Acharya
}

Florida International University, 2007

Miami, Florida

Professor Joel T. Heinen, Major Professor

The non-timber forest products (NTFPs) sector in Nepal is being promoted with the concept of sustainable management as articulated by the Convention on Biological Diversity. To promote and regulate this sector, Nepal adopted the Herbs and NTFP Development Policy in 2004. The goal of this thesis was to assess the effectiveness of this policy along with other forestry and natural resource policies in Nepal concerning the conservation and sustainable use of NTFPs. I conducted open-ended semi-structured interviews with 28 key informants in summer 2006 in Nepal where I also collected relevant documents and publications. I did qualitative analysis of data obtained from interviews and document review. The research found many important issues that need to be addressed to promote the NTFP sector as envisioned by the Government of Nepal. The findings of this research will help to further implement the policy and promote the NTFP sector through sustainable management practices. 


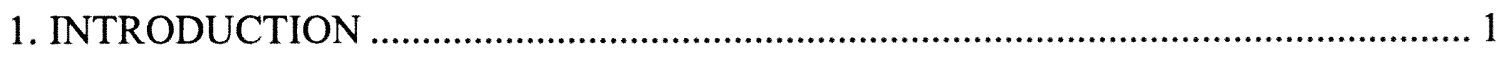

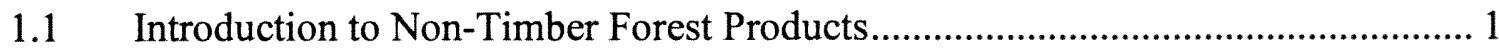

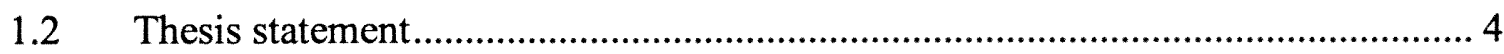

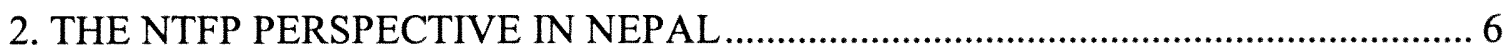

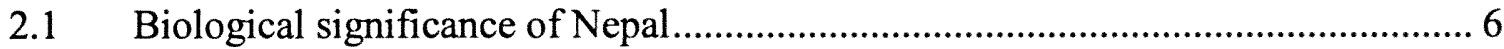

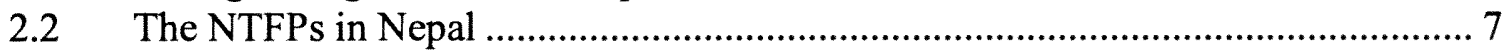

2.3 Conservation and sustainable management of natural resources in Nepal ............. 9

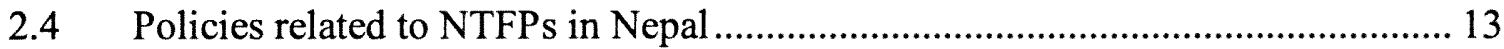

2.4.1 Herbs and NTFP Development Policy, 2004......................................... 13

2.4.2 Forest Act, 1993; Forest Regulation, 1995; and amendments ..................... 21

2.4.3 Rare (Endangered) Wildlife and Plants Trade Control Act, 2000 (draft).... 22

2.4.4 Implementation of the NTFP policy ............................................................ 23

2.5 Initiatives towards management of the NTFP sector by the stakeholders ............. 23

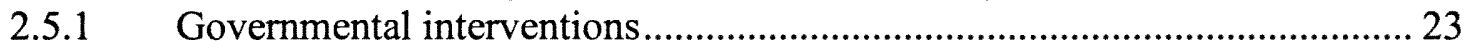

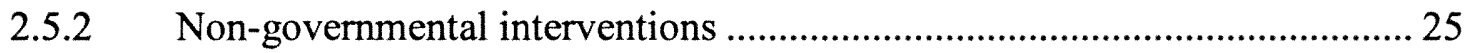

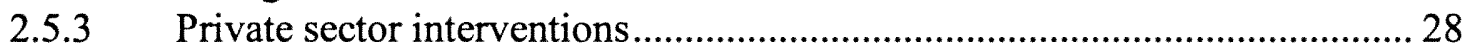

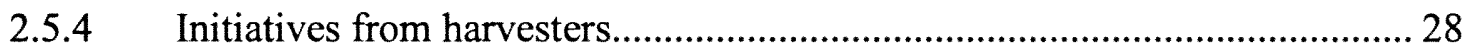

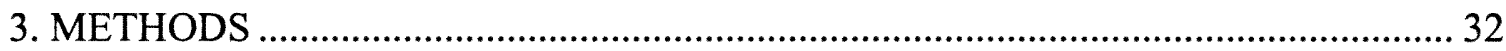

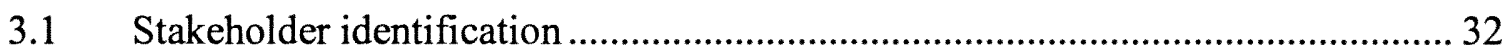

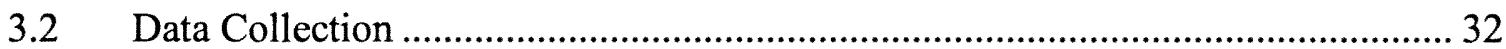





3.2.3 Data Collection Limitations and Constraints ................................................ 34

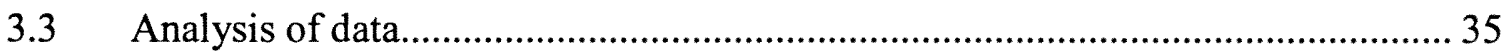

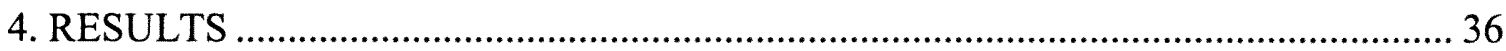

4.1 Major issues in NTFP management and trade .................................................... 36

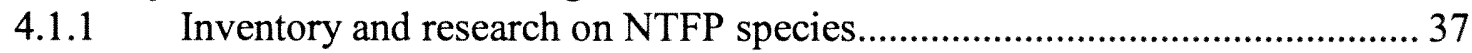

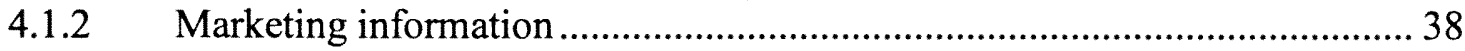

4.1.3 Capacity building and technology transfer .............................................. 39

4.1.4 Value addition and Enterprise development ............................................... 40

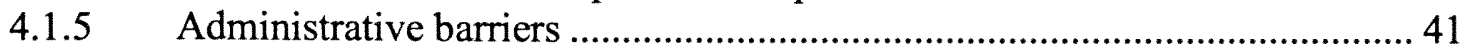

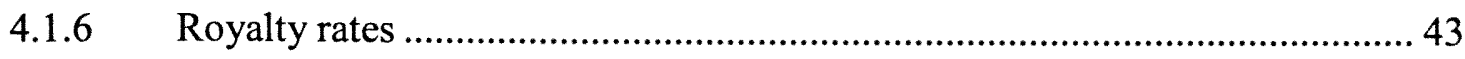

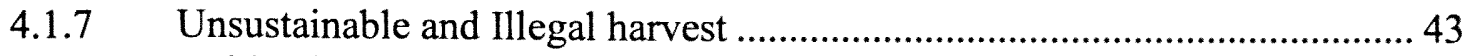

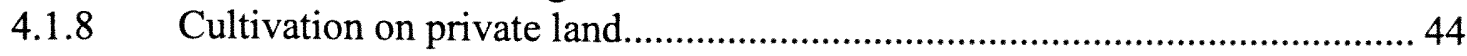

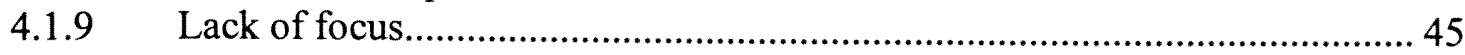

4.2 Impact of the Maoist insurgency on the NTFP sector ........................................45

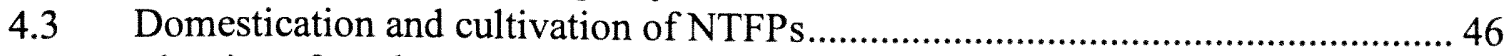






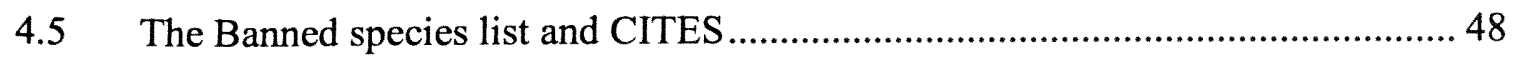

4.6 Policy implementation process ..................................................................... 50



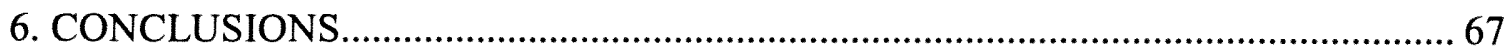

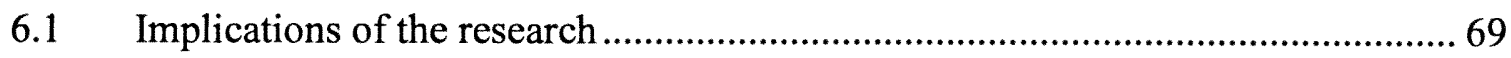

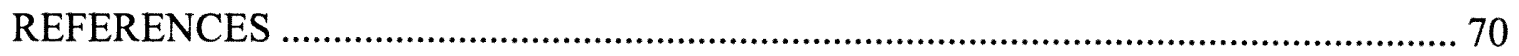

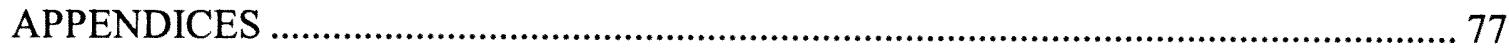




\section{LIST OF ACRONYMS}

AEC Agro Enterprise Center

ANSAB Asia Network for Sustainable Agriculture and Bio-resources

BDP-MaPS Business Development Services-Marketing Production and Services

CBD Convention on Biological Diversity

CECI Canadian Center for International Studies and Cooperation

CITES Convention on International Trade on Endangered Species of Flora and Fauna

DFO District Forest Officer

DoF Department of Forests

DPR Department of Plant Resources

EIA Environmental Impact Assessment

FECOFUN Federation of Community Forestry Users in Nepal

FNCCI Federation of Nepalese Chamber of Commerce and Industries

FUGs $\quad$ Forestry User Groups

HNCC Herbs and NTFP Coordination Committee

HPPCL Herbs Production and Processing Company Limited

ICIMOD International Center for Integrated Mountain Development

IEE Initial Environmental Examination

IUCN World Conservation Union

KMTNC King Mahendra Trust for Nature Conservation

MAPs Medicinal and Aromatic Plants

MFSC Ministry of Forests and Soil Conservation 
NEPHA Nepal Herbs and Herbal Products Association

NRs Nepalese Rupee

NTFP Non-Timber Forest Products

TMI The Mountain Institute

UNDP United Nations Development Programme

USAID US Agency for International Development

WWF World Wildlife Fund 


\section{INTRODUCTION}

\subsection{Introduction to Non-Timber Forest Products}

In the past, non-timber forest products (NTFPs) were thought to be minor forest products of local interest only and received less attention than timber resources (Arnold and RuizPerez, 2005). Wood-based products have also received more attention from the government and non-government organizations (NGOs) and even the scientific community. In the last several decades, there has been a shift within the conservation community towards sustainable management of natural resources, which includes the development of markets and organizational aspects along with ecological aspects. With this shift, NTFPs have been gaining much needed attention. NTFP management is coming up as a strategy for conservation as it is thought that the forest would remain intact if NTFPs are harvested in sustainable manner (Neuman and Hirsch, 2000). In addition, NTFPs are critical to rural subsistence livelihoods and contribute significantly to local, regional and global markets as well (Shanley et. al., 2002; Belcher et. al., 2005). The combination of NTFPs and timber can be an economically viable option to generate revenue for government and income for local users (Ashton et. al. 2001; Marshall et. al. 2006). Agenda 21, the key policy document of the United Nations Conference on Environment and Development in Rio in 1992, included a specific call for countries to address NTFPs in their forestry planning and management efforts for sustainable forest management (McLain and Jones, 2005). 
NTFPs include all biological materials extracted from forests for human use that are not timber (de Beer and Medermott, 1989). They range from edible and non-edible plant products such as fruits, nuts, seeds, leaves, herbs, medicinal plants, tubers, rattan, bamboo, fibers as well as bush meat and other animal products. However, plant products have been more important and extracted more often than animal products. The products range so widely that managers and researchers must be clear on what to include while defining policies for NTFPs before promoting projects, in order to avoid ambiguity (Belcher, 2003). There are thousands of species extracted from forests around the world which are integral parts of ecosystems. Humans have been dependent on forests from prehistoric times for everyday needs. People around the world have been dependent on them for subsistence, cultural values, traditions and spiritual needs. NTFPs have economic, social and ecological values as well as the complementary role that they can play to timber, agriculture and other land uses. The NTFP sector has helped in making the connection between conservation and development (Belcher, 2003).

However, there is a dearth of information on the economic and ecological impacts of NTFP extraction at national and regional scales. The economic contributions of NTFPs are difficult to estimate because of the lack of broad-based systems for tracking the combined value of hundreds of products that make up various NTFP industries (McLain and Jones, 2005). Global market trends have large and sometimes unexpected effects on biodiversity and its conservation. There is a lack of data and information on the ecology, use and management of even widely used NTFP species (Shanley et. al. 2002). Efficient inventory methods for NTFPs are required for sustainable management but forest 
inventory methods used for timber may not be efficient for NTFPs (Bih, 2006). Traditional ecological knowledge prevails where communities have been living in an area and are dependent on forests for their different needs (Bennett, 2002). Through adaptive management by trial and error they have learned the best seasons for harvesting various species, harvesting without harming other plant parts and leaving behind enough plants for regeneration. If this knowledge could be researched well, documented and further applied, it would be of great help in managing NTFPs (Wiersum, 1999).

Natural resource management for sustainable use needs policy instruments so as to make sure that resources are not depleted when economic activities are pursued. Sustainable forestry requires meeting human needs at present without sacrificing the ability to meet the needs of the future. Successes in environmental and resource management policies depend on the ability to synthesize various competing preferences and perspectives (O'Laughlin, 2004). Further, following the policy cycle framework is relevant to examine the consequences of implementation of the policy and make the changes required (Hoberg, 2001; Kraft and Vig, 2006). The challenge in formulation and implementation of appropriate policies is greater in developing countries since there is continued degradation of natural resources and associated decline in the sustainability of their use (Babu, 2000). NTFPs being a part of forestry, the forestry policy instruments applied will have an impact on management of NTFPs. Lack of specific policies for NTFPs may be a serious challenge for the management of the sector (Subedi, 2006). 
The NTFP sector is increasing in Nepal, a small Himalayan kingdom in South Asia between India and China. This thesis will explore several aspects of the NTFP sector in Nepal via key informant interviews, specifically focusing on plants and how they are being conserved and used at the national level. This study will try to find if similar trends on NTFP use as elsewhere exist in Nepal. The key question is: can conservation of NTFPs and economic tools used for subsistence livelihood through NTFPs go hand in hand? It needs exploring the role of national policy in promoting the conservation and sustainable use of NTFPs.

\section{$1.2 \quad$ Thesis statement}

Nepal has been quite active and progressive in the conservation and management of natural resources (Heinen and Chapagain, 2002). Over the years, it has formulated many policies on natural resource management which guide conservation initiatives. However, the nation is facing a problem of managing conservation along with sustainable use of NTFPs. The new policy, the Herbs and NTFP Development Policy, 2004, is a positive step for the development of the NTFP sector in Nepal. With the NTFP specific policy in place, in addition to the Rare (Endangered) Wildlife and Plants Trade Control Act, 2000, national legislation for the implementation of CITES (still is in draft form), effective implementation for management of the conservation, sustainable use and trade of NTFPs is a challenge facing the Government of Nepal. 
The major goal of this thesis is to assess the effectiveness of these NTFP related policies along with other forestry and natural resource policies in Nepal, on conservation and sustainable use and management of NTFP species, the focus being on the NTFP policy.

This research addresses the following general questions:

- What are the major issues concerning management and trade of NTFPs? Are the policies effective and sufficient to deal with these issues?

- What are the legal and administrative gaps in these policies that may affect implementation?

- What are the challenges faced by different stakeholders related to NTFPs use and trade?

- How is the government planning to manage NTFP-related policies in coordination with other natural resource policies? What contradictions and conflicts have emerged?

- Can the policies deal with conservation as well as sustainable use issues simultaneously? How successful are they likely to be in near future?

- What are the challenges for sustainable management of NTFPs in the country due to the Maoist insurgency and the state of political transition?

- What are the regional challenges for Nepal for effective implementation of CITES? 


\section{THE NTFP PERSPECTIVE IN NEPAL}

Since this thesis will focus on policy issues on NTFPs, specifically plants, in Nepal, this chapter gives background information on NTFPs use and management in Nepal. The biological significance of Nepal gives insight into the species of NTFPs found in the country. Information on ongoing conservation initiatives in the country, policy concerns and the relevant initiatives would help to direct the research. Here I will also look into the policies that are related to NTFP use and management in Nepal.

\subsection{Biological significance of Nepal}

Nepal is a small Himalayan Kingdom in South Asia known for its rich natural resources. One third of the total length $(3000 \mathrm{~km}$.) of the Hindu Kush Himalayan range, including the Mount Everest, falls within Nepal. All types of landscapes can be found in Nepal ranging from the Terai, the flat low lands in the south, the mid-hills in the central region to high mountains in the Hindu Kush Himalayan Region in the north. Nepal is a landlocked country bordered by China in the north and India in east, south and west. It has an area of 147,181 sq. $\mathrm{km}$. with altitudes ranging from 160 to $8848 \mathrm{~m}$. in a short $145-$ $241 \mathrm{~km}$. north-south distance (Figure 1).

Even though Nepal comprises only $0.09 \%$ of global land area, it has high diversity of flora and fauna at all three levels, i.e., genetic, species and ecosystem levels. It has dense tropical monsoonal forests in the Terai, deciduous and coniferous forests in subtropical and temperate regions in mid-hills, and sub-alpine and alpine pastures and snow-covered 


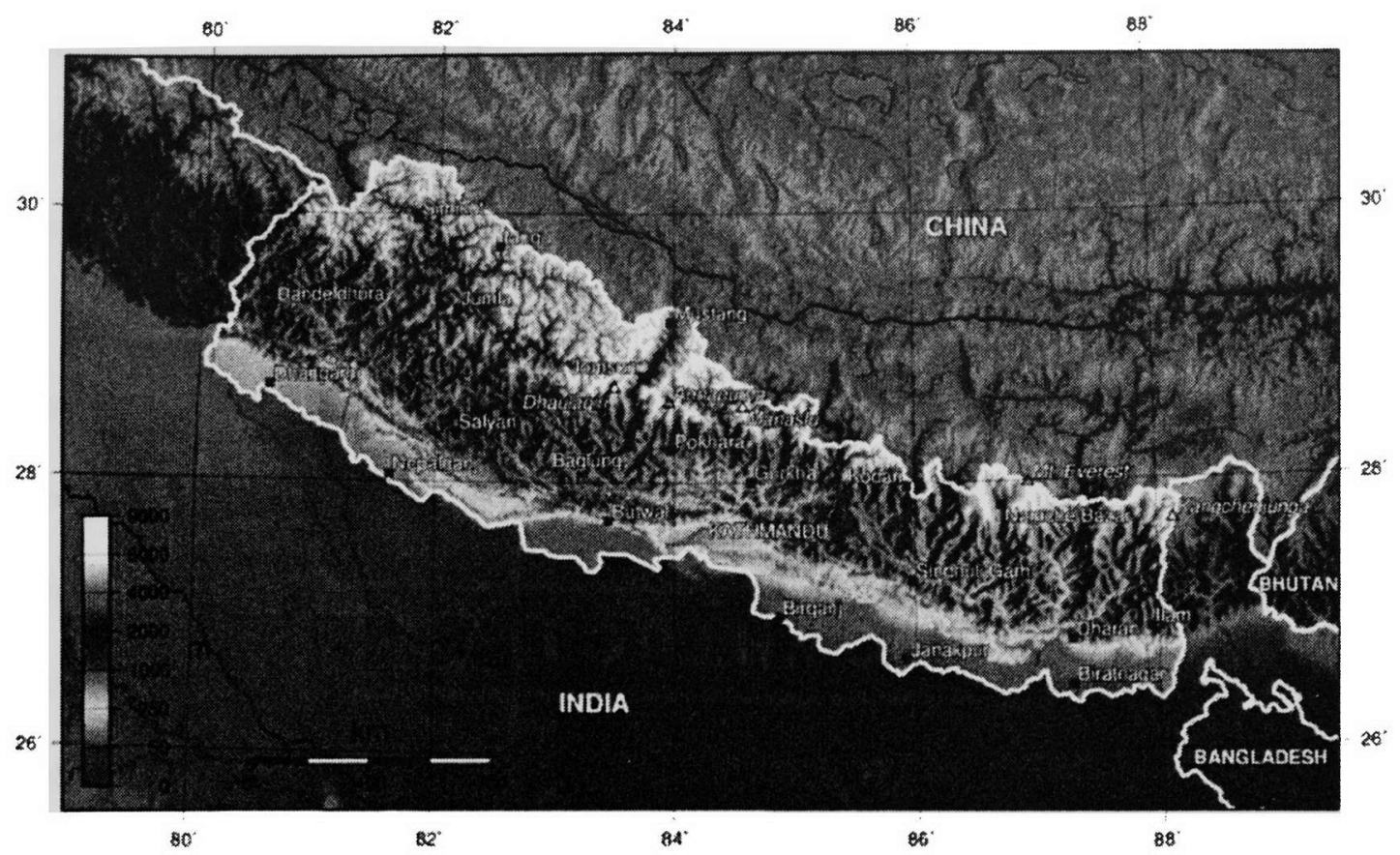

Figure 1: Map of Nepal (Source http://en.wikipedia.org/wiki/Image:Nepal_topo_en.jpg)

peaks in the high mountains. The forests comprise $29 \%$ of the total land area of Nepal with an annual deforestation rate of $1.7 \%$ (HMGN/MFSC, 2002). Nepal falls in the Palaearctic and Indo-Malayan bio-geographical regions and major floristic provinces of Asia. A total of 10,091 species of plants, including 5884 flowering plants, have been identified in Nepal, and among these, almost 700 have been identified to have medicinal properties which are often collected from the wild as NTFPs (HMGN, 2004).

\subsection{The NTFPs in Nepal}

Nepal has a wealth of NTFPs because of its diverse ecosystems. In Nepal, NTFPs include mainly herbs, fiber, raw materials, medicinal and aromatic plants. Among these, medicinal and aromatic plants are the most important as they are harvested the most both 
for domestic consumption and for export to international markets. The high elevation zones of Nepal are habitat to many medicinal and aromatic plants where people have the tradition of using healing herbs from nature (Shrestha, 2001).

Some important medicinal plants in Nepal include Rauwolfia serpentina, Terminalia chebula and Phyllanthus emblica in the tropical zone (below 1,000 m. altitude); Dioscorea deltoidea, Adhatoda vasica, Swertia chirayita, Cinnamomum tamala and Rubia manjith in the sub-tropical zone (between 1,000-2,000 m.); Aconitum ferox, Dactylorhiza hatagirea, Lycopodium clavatum, Taxus wallichiana, Juniperus recurva and Paris polyphylla in the temperate zone $(2,000-3,000 \mathrm{~m}$.$) ; and Nardostachys$ grandiflora, Rhododendron anthopogon, Picrorrhiza scrophylariaeflora, Rheum nobile, Cordyceps sinensis and Podophyllum hexandrum in the sub-alpine zone $(3,000-4,000$ $\mathrm{m}$.$) , and the alpine zone (>4,000 \mathrm{~m}$.). The steppic dry desert biome in the trans-Himalaya in northern Nepal is rich in Ephedra gerardiana, Hippophae tibetica, Artemisia spp. and Allium spp.

Culturally and traditionally, people in Nepal have been extracting NTFPs from the wild to meet many basic necessities (Chaudhary, 2000). Nepal has a population of 26.6 million with an annual growth rate of $1.9 \%$. The population below the income poverty level of US $\$ 1$ per day accounts for $24 \%$, and $68.5 \%$ live below the poverty level of US $\$ 2$ per day. A country with a GDP per capita (PPP) of US \$1490 (UNDP, 2006), the livelihoods of $85 \%$ of the people in Nepal depend on subsistence agriculture (HMGN/MFSC, 2002). Farmers depend heavily on forests and natural resources for agricultural and livestock 
practices. They use forests to extract fuel wood for cooking, fodder for livestock, timber for housing and NTFPs for medicine, spices and many other uses.

In addition, annual trade in medicinal plants and related products from the Himalayas including Nepal amounts to thousands of tons of roots, rhizomes, tubers, fruits, leaves, etc, that bring a cash value of millions of US dollars (Olsen and Bhattari, 2005; Olsen and Larsen, 2003). Sale of timber, firewood, NTFPs and MAPs together contribute nearly $10 \%$ of annual national GDP. NRs 14.9 million was generated as revenue in fiscal year 2001/2002 (Sharma, et. al. 2004). There are currently about 165 species of plants in trade of which 20 species cover $80 \%$ of the volume and value of commerce. Ninety-five percent of the NTFPs in trade are collected from the wild ie., from national forests, most of which are traded to India in raw form (CECI, 2006). Thus the government faces the challenge of the twin goals of conserving natural resources including NTFPs and at the same time improving the livelihoods of people.

\subsection{Conservation and sustainable management of natural resources in Nepal}

Nepal has been a leader in South Asia in natural resource management and has many success stories which could be an example for other countries in the region. Internationally, Nepal has actively participated in the conservation of biodiversity. Specifically, Nepal is a signatory to the Convention on Biological Diversity (CBD), the Convention on International Trade in Endangered Species of Wild Fauna and Flora (CITES), the Ramsar Convention and the World Heritage Convention. At the national 
level there are several policies, plans, acts and regulations in place to deal with issues of conservation and resource use of biodiversity. The Nepal Biodiversity Strategy, 2002, attempts to integrate conservation and sustainable use of biological resources for the benefit of people and to honor the obligations of the country regarding CBD.

The protected area system comprises $19 \%$ of the total area of the country and is managed by the Department of National Parks and Wildlife Conservation. In addition to in-situ conservation in protected areas, buffer zone management has been relatively successful, in a few of the protected areas where local communities have an incentive to manage/conserve the area as well as take benefit from it, though some research has shown it to be less participatory (Harini et.al. 2005) and question the monitoring capacity for its effectiveness in conservation and development (Heinen and Mehta, 2000). For example, the Chitwan National Park, which is world famous for royal Bengal tiger and one-horned Indian rhinoceros conservation, has a Buffer Zone Area Management Council. It receives an annual budget of 30-50\% from the Park's revenue and it has legal guidelines to spend these funds. It spends $30 \%$ on conservation, $30 \%$ on community development, $20 \%$ on income generation and skill development, $10 \%$ on conservation education and $10 \%$ on administrative expenses. In addition, community-based ecotourism has been a source of income for communities and works as an incentive to conserve resources. Several eco-clubs are campaigning against poaching both at national and at international level. There are community forests in the buffer zone where people are dependent for fuel wood and timber and where they are maintaining grasslands and aquatic habitats. The conservation measures taken inside the Park and in the buffer zones 
with community based management have led to an increase in numbers of endangered species as tiger and rhinoceros. However, the figures have been reported to decrease lately due to the Maoist insurgency which hit the nation hard in all sectors (Baral and Heinen, 2006).

Large areas of national forests in Nepal are managed by the Department of Forests. In many parts of the country, degraded forests have been leased to leasehold groups to manage for a period of 50 years. In addition to these, forestry programs in Nepal have been mostly successful where communities have been involved, i.e., forests have been better managed when communities are given management responsibilities than when forests are open access national resources. The Government of Nepal's policy is to adopt community forestry for all accessible Mid-hills and high mountain forests as well as in some Terai districts. Community forestry, with a history of more than 25 years, is a great success story in the region and community forestry user groups (FUGs) have been actively conserving and managing forests. The user groups, with a member from each household in the community, develop management plans with the help of district forest offices in which they have specific guidelines for pruning, logging, planting and harvesting of firewood, fodder and various products. User group committees see that guidelines are followed and resources are managed via sustainable approaches. During the last 28 years, about 1.2 million hectares of national forests (or 25 percent of existing forests outside of parks and reserves) had been handed over to more than 14,000 local FUGs (Kanel, 2006). 
Both national and community-based forestry programmes in Nepal have mostly focused on management of forests through sustainable use of timber and fuel wood, where the Master Plan for the Forestry Sector, 1988, has been the major guiding document (Chaudhary, 2000). The Forest Act 1993, the Forest Regulation 1995 and various amendments that are published in various government documents have been the major regulatory documents for the forestry sector, including NTFPs, in Nepal. In recent years, NTFPs have gained attention and importance in the forestry sector both as sustainable livelihood options for rural poor and as a source of revenue generation for the government, while having lower impacts on forests than timber harvest. There has been progress with in the management for this sector and Nepal has adopted the Herbs and NTFP Development Policy, 2004, which specifically deals with NTFPs, after a participatory process that involved stakeholders at all level (ANSAB, 2003). The Herbs and NTFP Development Policy promotes partly new initiatives and also articulates activities that are already underway in communities. A 13-member national level Herbs and NTFPs Coordination Committee (HNCC) has been formed under the chairmanship of the Minister of Forests and Soil Conservation of the Government of Nepal (Appendix 7). It was expected that the implementation of the new policy would help in conservation, management, trade and various activities necessary for the development of the NTFP sector since it focuses on sustainable management of NTFPs (Sharma et. al., 2004). In addition, the Rare (Endangered) Wildlife and Plants Trade Control Act, 2000, national legislation for implementation of CITES, has been drafted and also has many NTFP species listed in it appendices. In addition, the presence of the CITES Coordination 
Council and Implementation Unit is also a positive step towards cross-sectoral coordination (Heinen and Chapagain, 2002).

\subsection{Policies related to NTFPs in Nepal}

The Herbs and NTFP Development Policy, 2004 is the major policy for the NTFP sector in Nepal. The Forest Act, 1993, Forest Regulation, 1995 and amendments are also related to NTFP management in the country. Further, the Rare (Endangered) Wildlife and Plants Trade Control Act, 2000 (draft), national legislation for implementation of CITES in Nepal, is also related since trade in high value NTFPs is being promoted.

\subsubsection{Herbs and NTFP Development Policy, 2004}

The Herbs and NTFP Development Policy, was adopted by the Government of Nepal in 2004 (HMGN, 2004) (Appendix 6). This policy came into effect with a participatory method which could be considered both a bottom up and a top down process. Various rounds of consultations and workshops were initiated so as to include all stakeholders. Pertaining to the growing trade on NTFPs, mostly medicinal and aromatic plants, the various stakeholders felt that there is a need of policy for the management of NTFP sector. The consultations started from local user groups facilitated by FECOFUN and $\mathrm{ANSAB}$ and at the end there was a national level workshop for designing the elements of the policy. So whole through the process government bodies, non-government bodies and the local users took the initiative. 
The implementing body is the Ministry of Forests and Soil Conservation of the Government of Nepal and the process requires coordination between two Departments ie., the Department of Forests and the Department of Plant Resources. As previously mentioned there is a 13 member national Herbs and NTFP Coordination Committee which is officiated in the Department of Plant Resources (Appendix 7). It has a facilitative role to play for the implementation of the policy.

The Herbs and NTFP Development Policy, 2004, focuses on sustainable management of the NTFP sector in Nepal. The long term vision of this policy is to help the economy through conservation and sustainable management of high value NTFPs and make Nepal well-known worldwide as a source of Herbs and NTFPs. The policy has the following six objectives:

(i) Sustainable management of NTFPs in the wild so as to help in the regeneration of species and obtain maximum economic and environmental benefits

(ii) Cultivation of important NTFPs for commerce so as to help in ex-situ conservation of species as well as help in the national economy and employment

(iii) Promote primary processing and value addition of NTFPs at the local level so as to increase employment and income in remote and rural areas and increase participation of local private sectors so as to enhance local economies

(iv) Aid in commercialization of NTFPs by providing capital, infrastructure, technical knowledge, skill and marketing management so as to help in poverty alleviation and improve livelihoods of local people 
(v) Ensure participation of disadvantaged, poor and women in communities in the collection, processing, production and marketing of NTFPs and help in natural resource management through gender and social perspectives

(vi) Promote the NTFP sector to be competitive in the global market so as to help in the national economy.

The six objectives of the policy are addressed through strategies that focus on the following five areas.

1. Conservation and management focusing on the concept of sustainable development: The policy proposes to conserve and manage the NTFP sector by initiating inventories of natural sources of herbs and NTFPs and developing criteria for good harvesting practices that help in natural regeneration. In-situ and ex-situ management for the conservation of endangered species of herbs and NTFPs is to be done. It promotes the study of the availability of NTFPs and declares certain areas of the country as "NTFP zones". Further, it focuses on developing competitiveness in the collection of herbs and NTFPs available in districts and focuses on creating maximum benefits to local inhabitants and entrepreneurs. For this, it attempts to find the national and global market demands of herbs and NTFPs and ensure constant supplies through cultivation or natural forests. The Herbs and NTFP coordination committee (HNCC) is given a major role in monitoring and evaluation of policies and programmes in the NTFP sector. Separate short term and long term plans are to be developed and implemented for the overall development of herbs and NTFPs which is to be facilitated by HNCC. 
2. Promotion of the participation of people:

This strategy focuses on three areas: enrichment plantations in forests, value addition and development of marketing networks. Since natural sources may not be enough for the commercialization of herbs and NTFPs, cultivation in leasehold forests, community forests and other private forests, and by groups, would be promoted. In this process various user groups in the forestry and farming sectors would be involved. Women who are below the poverty line would be given priority and ensured that they get maximum benefit. Further, the policy proposes to do value addition to NTFPs at the local level, which can be processed within the country. For this it will promote government, private and related local organizations in this sector and develop infrastructure. For the marketing of NTFPs, the policy plans to develop marketing networks among harvesters, collectors and sellers of herbs and NTFPs so as manage the sector. The private sector and cooperatives will be promoted in marketing and export.

3. Simplify the certification and taxation process:

This strategy of the policy focuses on two aspects: the certification of NTFPs that are cultivated in forests and private lands and simplification of the government taxation process. Since the first strategy promotes sustainable management and cultivation of NTFPs in forests such as leasehold and community forests, and also private lands, this strategy looks into the certification process of such products. It proposed to make the marketing of herbs and NTFP species that are cultivated both in processed or unprocessed form easier. Further, it promotes forest certification for NTFPs that are collected based on sustainable management. In addition, it initiates organic farming 
certification processes. For this, it proposes to strengthen laboratories for characterization, mapping and identification of genetic diversity of plants and for biotechnological study. Further the policy proposes to revise the royalty rates of herbs and NTFPs that are collected from forests and to base those on the local market prices obtained by the collectors. Royalty rates would be updated every five years.

4. Make research and development accessible to communities:

This strategy of the policy focuses on identifying, inventorying and developing cultivation techniques for NTFPs that have prospects for commercialization. Further, research would be initiated to identify medicinal and aromatic oils found in plants. The chemicals that have been already researched would be promoted for processing and isolation to help in commercialization. This part of the policy proposes to disseminate research results to forestry groups, farmer groups and to those involved in soil conservation programmes. The various organizations that are working on research and development of herbs and NTFPs would be coordinated so as to avoid overlap of efforts. The scope for bio-prospecting would be looked into via contacts with international organizations so as to get benefits from the plants found in the country. To ensure maximum benefits for Nepal, the possibility of marketing of genetic resources in international markets will also be explored.

5. Facilitate skill development and commercialization process through awareness:

This portion of the policy promotes awareness about collection, management and cultivation techniques of NTFPs. Opportunities for skill development would also be 
provided. The policy states to give special consideration by the government to any persons or groups who are interested in cultivation, processing and marketing of herbs.

The work plan for the above mentioned five strategies has been further explained under the list of twenty eight points which are discussed in the following paragraphs:

The NTFP policy states that government will continue to play a role of facilitator, catalyst and regulator in the collection, production, cultivation and processing of NTFPs mainly through cooperatives and also by the private sector. The cooperatives formation process would be promoted in Nepal to allow groups to gain benefits through production and development of herbs and NTFPs. The loan processing would be facilitated through agricultural development banks or other organizations for cultivation, collection, processing and marketing of herbs and NTFPs by groups, cooperatives and the private sector. It also promotes the process of registration of the area of cultivation of herbs and NTFPs on private lands through district forest offices. Environmental policies and plans would be reviewed so as to help facilitate in the process of commercialization of herbs and NTFPs.

The policy also promotes value addition through scientific methods in storing, processing, packaging and extracting chemicals from herbs and NTFPs found in Nepal. For this, development of small scale enterprises at the local level would be given priority and the government will give required technical and financial support. Further it promotes continuity of raw materials for such industries by collection and cultivation of relevant species, and it promotes cottage industries in the NTFP sector. 
The policy promotes the process of documentation of NTFPs found in Nepal so as to get statistics on natural production that will help in sustainable harvest. The NTFP sector would be included in management plans of leasehold and community forests to promote cultivation, and the user groups would be provided with knowledge, skills and financial support. It also promotes cultivation and collection of NTFPs in government managed forests through the private sector and cooperatives.

The policy briefly mentions the preservation of traditional knowledge about NTFPs and encourages documentation of such knowledge. Then it states to make relevant changes in traditional techniques of production, collection, use and management of herbs and NTFPs and promote and develop modern technology. The policy also proposes to declare certain parts of the country as "NTFP zone" based on the availability of herbs and NTFPs. Local participation in the development, management and conservation of NTFPs and initiate income generating activities in such areas is encouraged.

The NTFP sector will be promoted by various mechanisms such as organizing NTFP fairs with the help of various bodies such as market promotion centers, the Nepal Federation of Chamber and Commerce and international diplomatic offices to gain access into international market for NTFPs found in Nepal. Such fairs would be organized inside the country at the district level as well. Display centers for NTFPs would also be developed. 
The policy proposes to include the sector in academic courses related to natural resource management. It promotes capacity building of government and non-government organizations at national and local levels involved actively in the herbs and NTFP development sector. Further, it proposes to integrate the NTFP sector in various local development programmes, specifically for farmers, women and disadvantages groups. The use of marginal and un-used lands which are unsuitable for agriculture would be promoted and the loan process by the agriculture development banks would be facilitated for NTFP cultivation.

The policy also states to develop marketing information networks to give information on national and international markets to producers, collectors, processors and exporters. It promotes the establishment of national and regional level market information centers. It also proposes to maintain minimum standard of NTFPs from Nepal to promote marketing in third countries. The standards of laboratories would be enhanced for identification and testing of NTFPs for quality control. The plan is to gradually develop companies that are under government licensing to deal with on cultivation, collection, production, processing and marketing of NTFPs according to market demand.

Overall, the Herbs and NTFP Development Policy is highly focused on commercialization of NTFPs in Nepal and how this can be used in economic development of local people. As a result, the policy does not mention much about conservation aspects of NTFPs and regulation of the sector. Throughout the policy the two terms - cultivation and collection - are used together and it becomes unclear whether 
the specific point is for collected species or for cultivated species. The two perspectives would give very different implications for management. Further, the policy does not mention specifically who is going to implement it, even though there is an understanding that two departments - the Department of Forests and the Department of Plant Resources, under the Ministry of Forests and Soil Conservation, would be involved. It is unclear which department is going to do what and the two departments are never mentioned specifically in the text of the policy.

\subsubsection{Forest Act, 1993; Forest Regulation, 1995; and amendments}

The Forest Act, 1993; The Forest Regulation, 1995; and the amendments have been major guiding documents for the regulation of the forestry sector, including NTFPs. The Department of Forests is the regulatory body that implements theses policies. Most of the NTFPs collected and traded in Nepal come from the wild, from within national forests and national forests are under the jurisdiction of the Department of Forests. There are 75 districts in Nepal and all but one (Mustang) have district forest offices. The District Forest Officers (DFOs) have authority at the district level and oversee all activities in national forests including leasehold and community forests.

Before the collection season every year, NTFP collectors are required to get permits from the respective DFO. This document specifies the amount of a specific NTFP that can be collected within the specified timeframe from a specified locality. The collected NTFPs

are to be brought to the district forest office to pay royalties before materials can be 
traded. The Forest Regulation has specified royalty rates for more than 200 species and they are updated every five years (Appendix 5). If the collector plans to harvest more than 5 tons of an NTFP, Initial Environmental Examination (IEE) is required. There is a specific method for IEE before the permit can be issued by the DFO (MFSC, 2005). If harvest is more that 50 tons, then an Environmental Impact Assessment (EIA) is required before the permit is issued.

The Forest Regulation, 1995, has protected 18 plants in Nepal among which two are NTFPs that are totally restricted for collection, use, sale, transport or export (Appendix 3). Further, nine species are banned for export except in processed form and seven tree species are banned for commercialization and export. Due to recent changes, Picrorhiza scrophulariflora, which was totally restricted earlier, has been banned for export except under recommendation of the Department of Plant Resources (Appendix 3). It was found out that it is a different species from Picrorhiza which was banned under CITES.

\subsubsection{Rare (Endangered) Wildlife and Plants Trade Control Act, 2000 (draft)}

The Rare (Endangered) Wildlife and Plants Trade Control Act, 2000, which is still in draft form is national legislation for the implementation of CITES in Nepal. Since the collection and export of high value NTFPs are on the rise in Nepal, this policy is also related to regulation of sector. There are some NTFP species that have been listed in Appendices of this Act (HMGN/MFSC, 2002). There are a total of 15 species and families listed in its appendices. The Appendix I lists 1 species, Appendix II lists 9 
species and Appendix III lists 5 species (Appendix 4). Of these three are high value NTFPs in Nepal.

\subsubsection{Implementation of the NTFP policy}

Even though the Herbs and NTFP Development Policy, 2004 came out 3 years back there are no regulations yet in place for its implementation. The deteriorating political situation due to the Maoist insurgency that affected the country hard for more than 10 years affected all sectors of the economy. The Maoist insurgency has been a major threat towards effective management of natural resources and has complicated conservation (Baral and Heinen, 2006). Nonetheless, the government and non-government sector have tried to put efforts toward working with issues on NTFPs.

\subsection{Initiatives towards management of the NTFP sector by the stakeholders}

In Nepal, NTFP management can play a role in all aspects ranging from conservation to social and economic development. However, management, trade and research efforts need to be coordinated. There are various sectors that have been putting effort towards managing the NTFP sector thus they are the stakeholders of the sector.

\subsubsection{Governmental interventions}

The Department of Plant Resources (DPR), a body under the Ministry of Forests and Soil Conservation, conducts research and development on medicinal plants and germplasm 
conservation. It has herbal farms in seven locations in the country where it is experimenting on cultivation of medicinal plants. However, in comparison to the vast natural resources present in Nepal, this initiative needs expansion (Sharma et. al., 2004). The National Herbarium and Plant Laboratory of DPR has explored plant diversity around the country and collected herbarium and ethno-botanical information. If utilized to the full extent, this information could be a tool to inventory or monitor different important NTFPs. In addition, the Natural Products Research Laboratory of DPR does phyto-chemical screening of Medicinal and Aromatic Plants (MAPs).

A total of 219 plants have been studied and could be used to raise the income of the country through value-added products instead of exportation in raw form. The Herbs and NTFP Coordination Council has prioritized 30 species of NTFPs for further research and promotion (Appendix 8). Further, out of these, 12 species are prioritized for agrotechnology development - farming techniques development for farmers in commercial cultivation - which have good prospects of being cultivated on private lands. These species include: Asparagus racemosus, Cinnamomum glaucescens, Dactylorhiza hatagirea, Nardostachys grandiflora, Picrohiza scrophulariflora, Pier longum, Rauvolfia serpentine, Swertia chirayita, Taxus wallichiana, Tinospora sinensis, Valeriana jatamansi and Zanthoxylum armatum. The DPR has brought out, with the recommendation of $\mathrm{HNCC}$, a publication that gives information on distribution, uses, cultivation techniques and the conservation status of these 12 prioritized species (HNCC/MFSC, 2005; DPR/MFSC, 2005). This could be a good step towards conservation as some of these plants have threatened and endangered status under IUCN. 
In a country where a mere $0.7 \%$ of GDP is spent on Research and Development (UNDP, 2006) these initiatives are quite appreciable.

Community Forestry User Groups in certain parts of the country have been encouraged by the government to revise their management plans and cultivate MAPs in community forests to promote conservation and sustainable use with the adoption of NTFP policy. However, this requires technological and scientific intervention in extension programmes that includes selecting the right species, proper cultivation, harvesting, grading, storage and cooperative arrangements for better markets (Subedi, 1999). Further, the government has companies such as the Herbs Production and Processing Company Limited (HPPCL) and Singhadarbar Vaidhyakhana, which produce and trade various herbal products using NTFPs.

\subsubsection{Non-governmental interventions}

Various donor-driven international non-governmental organizations (INGOs) are quite active in the country. The World Wildlife Fund (WWF), The World Conservation Union (IUCN), The International Center for Integrated Mountain Development (ICIMOD), United Nations Development Programme (UNDP), SNV Netherlands Development Organization (SNV), CARE Nepal, CECI Nepal are some of the major INGOs in Nepal that promote this sector through Integrated Conservation and Development Projects (ICDPs). They have different projects around the country that give technical support at the community level where they have capacity-building programmes for local 
organizations and forestry extension programmes for communities. Among the national level non-governmental organizations, the King Mahendra Trust for Nature Conservation (KMTNC) and the Asia Network for Sustainable Agriculture and Bio-resources (ANSAB) are quite prominent. ANSAB has been instrumental in the formulation of the Nepal NTFP alliance and has been able to bring different sectors on board into one platform. All these organizations play a role of facilitator working as partners with government bodies and with communities. The support ranges from technical and financial to initiating enrichment plantations of NTFPs in community forests.

The Alliance project of ANSAB which was funded by various donors has made significant progress in promoting forest certification in Nepal. This project piloted the Forest Stewardship Council's (FSC) forest management certification process. A total of 36 Forestry User Groups (FUGs) comprising 7,198 households and covering 17,031 hectares of forest areas have received technical assistance and international forestry certification observation visits. Two districts in Nepal, Dolakha and Bajhang, received FSC forest management group certification where a total of 21 forest user groups with 14,086 hectares of forests are involved. This is the first NTFP certification in Asia and only the fifth in the world. In addition, eight forest-based enterprises have received FSC Chain of Custody certification (ANSAB/USAID, 2005). The certified species include Daphne bholua and Edgeworthia gardenerii which are used for production of hand-made paper; Gaultheria fragrantissima used for extraction of essential oil, Girardiana diversifolia used for cloth production; and Parmelia sps., Rubia manjith, Berginia ciliate, Swertia chirayita, Paris polyphyla, Rheum australe, Silenum cadollei, Morchela 
sps., Valeriana jatamans, Picrorhiza scrophulariflora, Nardostachys grandiiflora, Aconitum Heterophylum with medicinal uses. Forest certification ensures that the products are from the sources that have been managed sustainably and not overexploited. Further it ensures that environmentally sound ecological practices have been followed for extraction so that the species are not depleted. The Federation for Community Forestry User Groups (FECOFUN) works as a resource manager for FUGs in the certified pool. FSC forest certification comprehensively covers social, environmental and economic elements. The participating FUGs have to revise their operational plans, constitutions, systems and practices in line with the principles and criteria of forest certification. Selection of FUGs is important for NTFP certification which is based on several criteria such as richness in NTFPs, potential for sustainable management and harvest, institutional and resource management capacity, monitoring and auditing systems. The alliance project has also added the organic certification program to promote international marketing of NTFPs.

FECOFUN, with the help of ANSAB and others, has developed guidelines for identifying and protecting rare, threatened and endangered species. The FUGs have been provided with a copy of the IUCN Red List of species for Nepal and a number of FUGs are already implementing the guidelines. FECOFUN has also developed a monitoring format for FUG members to monitor changes in forest conditions. Further, FECOFUN and ANSAB bring out the pricelist of the NTFPs at various markets which is updated monthly and made available to the traders and user groups. 


\subsubsection{Private sector interventions}

Quite a few private enterprises are also taking initiative in the development of the NTFP sector. Among those, Dabur-Nepal Pvt. Ltd. is a leading multi-national company that deals with herbal products in Nepal. Dabur has been initiating research on selective NTFPs on its private farm. In addition, it is initiating private farm cultivation in a western district, Jumla, where it has an agreement with farmers in which it will supply the technology to cultivate the species on their private land and supply seeds and plants produced in monitored conditions in their greenhouse and farm. In the harvest season, Dabur-Nepal buys raw materials cultivated on private lands to make various ayurvedic products. This initiative is a very good prospect for further research, conservation and market development of NTFPs. In addition the International Center for Integrated Mountain Development (ICIMOD) and the International Fund for Agricultural Development (IFAD) are collaborating with Dabur-Nepal to involve the corporate sector into research and development of NTFPs (Anil and Kerkhoff, 2005).

\subsubsection{Initiatives from harvesters}

Recently, some farmers have started to cultivate medicinal plants, which could be replicated elsewhere in the country (Chettri and Sharma, 2006, ICIMOD, 2004; Malla et. al., 1999). Development of this opportunity could be a great economic incentive for farmers while at the same time reducing exploitation of non-timber resources in government forests. Specifically in eastern Nepal, where there is a high demand for chiraito (Swertia chirayita), a herb widely used for its medicinal properties in traditional 
medicine, some progressive farmers have started to cultivate the species on their land using indigenous technologies and to sell to international traders (Sharma et. al. 2004). Local harvesters know seasons and how to select plants that are ready for harvesting, how to harvest species without harming other plants and without injuring the plant itself. However, policy hurdles requiring certification of products that are cultivated on private forestry are a great disincentive for people (Ojha, 2000). Thus, there is a need for policies regarding private cultivation, production and marketing of NTFPs. Local harvesters and entrepreneurs face many constraints in marketing medicinal plants: the uncertainty of markets and price fluctuations; legal hurdles where royalties as at times higher than sale prices; and competition in international markets. The NTFP policy of 2004 has tried to address these issues.

In Humla, a remote district in western Nepal, user group enterprises growing jatamansi (Nardostachys grandiflora), a herb with essential oil extracts in its rhizome that is used in perfumery, enhance the restoration and conservation of forests and increase incomes in the area that, in turn, generated an interest in conservation (Sharma et al. 2004). In 1995, the Biodiversity Conservation Network supported a community-managed jatamansi essential oil processing enterprise, Humla Oil Pvt Limited. The local communities and their institutions do processing, management, and marketing of the enterprise with support from ANSAB and its partners. Another example in Bajhang, Nepal, relates to the Kailash Forest User Group (KFUG). KFUG formed a company called Malika Handmade Paper Pvt Ltd. The company was supported by ANSAB in 1999 to produce hand made paper using lokta (Daphne bholua), a shrub whose bark contains high quality fiber that is 
used for making paper. Forest user group members conserve lokta in natural habitats and harvest it sustainably for resource conservation, as well as conducting research on regeneration methods for on-site and off-site conservation. Records are maintained and periodic meetings are organized to review progress, develop strategies, and obtain feedback. The annual turnover of the factory is NRs 294,000 (US\$ 4200) and profits during 2003 were NRs 105,000 (US\$ 1500). In another study, Olsen and Hells (1997) found that in the northern and middle parts of the Gorkha district in central Nepal, $25 \%$ to $100 \%$ of households in a given village participate in collection and that the average daily income is competitive with other income-generating activities in the area. All these examples, where local communities are involved in private cultivation and enterprise, help in conserving resources in government managed forests that are usually open access forests due to the absence of regulatory bodies in remote areas. People are dependent on such open-access areas to meet subsistence needs. However, if they are able to make extra income by getting involved in these small scale enterprises, they would not go to open access government forests.

Further, even though not meant primarily for NTFPs in the forest, indigenous protection systems for forest management are in place in many parts of the country which have been indirectly benefiting the conservation of NTFPs (Subedi, 1999). In many parts of the country sizable chunks of forests are set aside, managed and protected by local communities for religious value which are usually linked to protection of watershed areas. In such areas communities have their own rules and usually follow them. Further, communities, especially older generations, have indigenous knowledge about NTFPs, but 
it seems different in various social groups and categories. Usually groups who are most dependent have the most knowledge (Ojha and Bhattarai, 2003). There is heterogeneity of knowledge and practices within any area and this is important to consider in designing sustainable management practices (Ghimire et. al. 2004). 


\section{METHODS}

\subsection{Stakeholder identification}

Since the NTFP sector includes various stakeholders in Nepal, the implementation of the NTFP policy calls for the inclusion of thoughts, ideas and experiences of all stakeholders. The list includes governmental organizations, which are the direct regulatory bodies for NTFP related policies. These are the Department of Forests and the Department of Plant Resources under the Ministry of Forests and Soil Conservation of the Government of Nepal. It also includes the Herbs and NTFP Coordination Committee. As mentioned earlier, the various national and international NGOs that directly implement different programmes and ICDPs across the country also play a major role in the NTFP sector in a developing country like Nepal. Further, key informants included researchers from the forestry and botany disciplines. There are a few organizations involved in processing and trading of NTFPs which include governmental and private companies as well as community user groups. The list of key informants was generated based on a literature review that gave insight into who are working in the NTFP sector. Further, the list increased during the data collection as I found there were more stakeholders and also some were recommended by the key informants themselves.

\subsection{Data Collection}

The field research was carried out through open-ended and semi-structured face-to-face interviews with key informants from various stakeholder groups in the NTFP sector following Bernard's (2002) methodology. The key informants included various personnel 
from different organizations that are directly related to decision making, implementing the policies and programmes relating to NTFPs and those impacted by the policy. Further, I collected relevant reports and publications from the key informants as well institutional libraries in Kathmandu. These documents are often not easily available outside Nepal as it is a developing country with not very wide use of the internet.

\subsubsection{Interview procedure}

The field work was carried out in the months of June, July and August of 2006 in Kathmandu, Nepal. Due to the unstable political situation in Nepal, it took longer to complete all the interviews as there were times when the offices were closed for days and roads blocked unpredictably. The open-ended semi-structured interview was carried out with a total of 28 key informants (Appendix 1). There were 8 key informants representing governmental organizations, 11 representing non governmental organizations, 5 representing traders/harvesters and 4 representing researchers. I scheduled appointments with the informants beforehand. The interviews, being open-ended discussions, were taped on audio cassettes. Previous approval was sought from all key informants before taping interviews and, all except one approved. The key informants were provided with major questions (Appendix 2) to discuss, but were not limited to those, and copies were kept for each informant to make notes as they talked. These notes helped later in transcribing tapes. Most of the interviews were one hour long on average. After interviewing I labeled tapes with the name and organization of the key informant. Looking at the list of key informants that I had prepared before the interview process, I 
had expected that most of the interviews would be conducted in English, since English is the second language in the education system of Nepal and most people, especially personnel working in government and NGOs. In spite of this, most key informants preferred to speak in Nepali because they thought that the discussion would be more rigorous in one's own language and this was not a problem since my (researcher's) mother tongue is Nepali. The informal nature of semi-structured interviews gave interviewees more flexibility leading to productive discussions.

\subsubsection{Transcription and Translation}

I brought all audio cassettes to the United States to transcribe, which took 2-3 hours per cassette to transcribe fully. At times I had to re-listen to cassettes to make sure that I did not make any mistakes and my earlier notes, which I had made during the interviews, were very handy on such situations. Then, since most of the interviews were in Nepali, I translated them all into English. Transcribing and translating the interviews was a very lengthy process.

\subsubsection{Data Collection Limitations and Constraints}

The unstable political situation in Nepal made the data collection process a bit lengthy. In addition, field work outside Kathmandu was not feasible. Thus, some of important stakeholders, such as DFOs and user groups in important NTFP collection areas could not be interviewed. Another striking feature that came out was that none of the interviewees 
were female even though I tried to find female informants. Hence, the gender perspective was not represented.

\subsection{Analysis of data}

For the analysis I followed a qualitative method and for assessment I used data from two sources. One was from the key informant interviews ie., the transcriptions of the semistructured interviews of key informants. The other was from the review of the documents that I had collected during my field research in Nepal. I had collected a sizeable amount of documents and literature from key informants as well as institutional libraries in Nepal.

I used the grounded-theory approach to analyze the data (Bernard, 2002). In this I tried to find categories and concepts that emerged from transcribed texts. Then I tried to analyze the data surrounding the emerged themes and tried to compare answers. This is a constant comparison method which involves examining data for similar cases and patterns (Ausband, 2006).

Further, through the analysis I tried to capture different issues, remedial measures and success stories about NTFPs conservation and use from the documents and literature collected. I tried to relate these to the analysis of key informant interviews and tried to analyze the NTFP policies in Nepal. 


\section{RESULTS}

\subsection{Major issues in NTFP management and trade}

There were many issues in the NTFP sector in Nepal that came up during the interview process. Discussions on these issues are important for the analysis of the NTFP related policies in Nepal. The following were stressed by the interviewees as major issues (Figure 2) for the development of the NTFP sector.

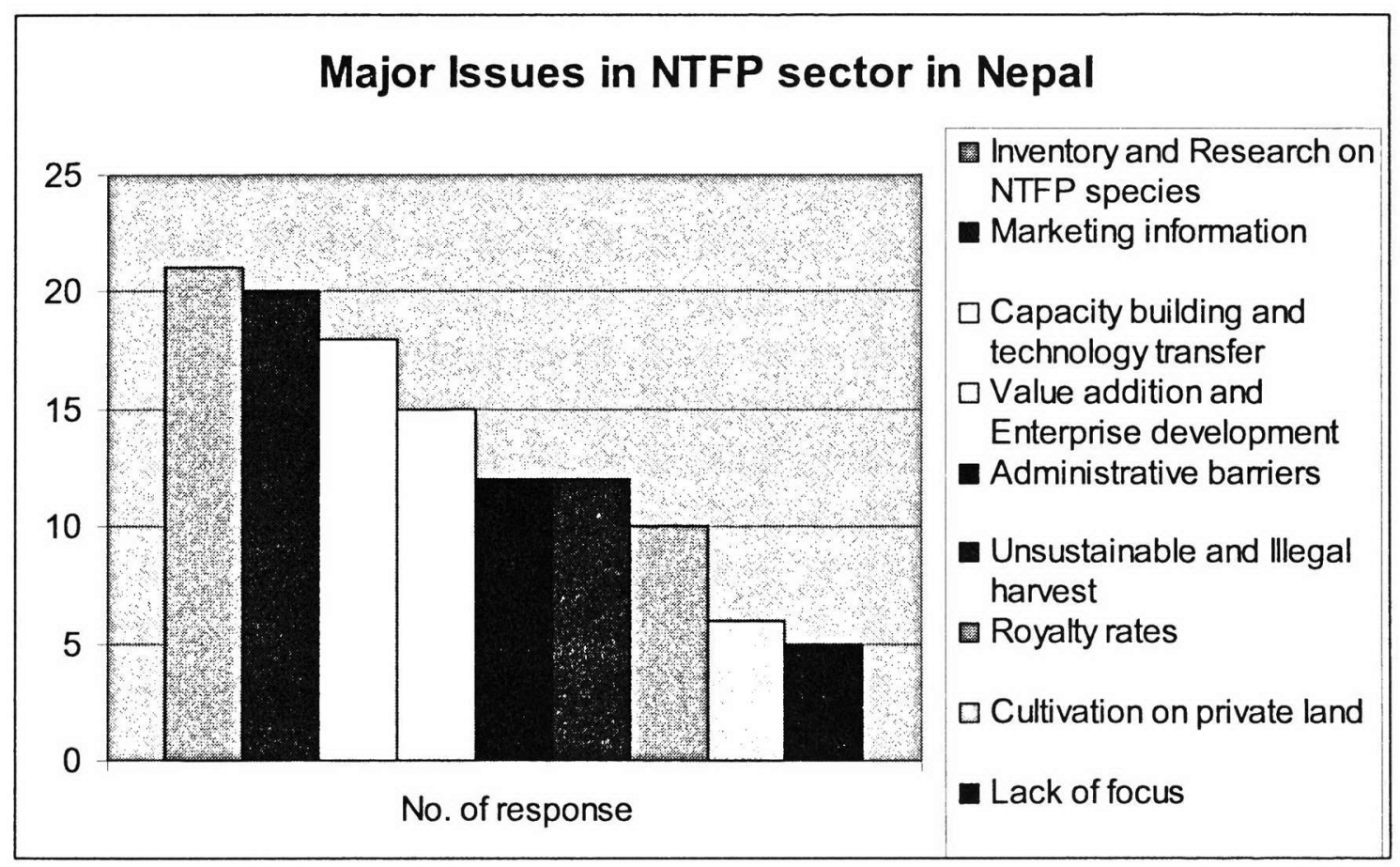

Figure 2: Major Issues in NTFP sector in Nepal - Interview Results

The need for inventory and research on NTFP species was stated as the biggest issue followed by the lack of marketing information. The need for capacity building and technology transfer were also cited as major issues by more than half of all informants. Value addition and enterprise development requirements; administrative barriers; and unsustainable and illegal harvest of NTFPs were also cited by nearly half of all 
informants. Further, a few informants thought that cultivation on private lands and lack of focus in this sector as an issue. Following are the details of the issues that were discussed during key informant surveys.

\subsubsection{Inventory and research on NTFP species}

A total of 21 key informants thought that the need for inventory and research on NTFP species is a major issue in this sector. They thought that there is a dire need for inventory of NTFPs in Nepal to find out what is there and in what quantity. What species are there, what are their habitats, what is their status, are they abundant or declining? According to them, all these need to be assessed. Further, they said that there is a need to have a complete list of NTFPs in Nepal. At present, information is scattered and there is no linkage. Identification and inventory of NTFP species is very important for sustainable management. Lack of databases on resource stocks makes it difficult for forest offices to issue harvest permits.

"We talk about harvesting but do not know the benchmark; we do not know the areas where they grow. There is a need for more research background. The research from neighboring countries can also be used." (Informant \# 5, NGO sector)

Further, the informants thought that the definition of NTFP should be clarified and standardized. According to some informants many people think that fodder can be included in NTFPs, while many others think of NTFPs as a synonym for medicinal 
plants. Further, research is needed on the management of species to find out what are more potentially profitable strategies. Eg. In west Nepal it is said that there is a trade worth millions of dollars in yarshagumba (Cordyceps sinensis), a rare and unique species that is half mushroom and half caterpillar with use as aphrodisiac and tonic in Chinese medicine; but no one knows the volume. In addition, to complicate the matter further, there is a lack of specialists in this sector. For example, in Singhadarbar Vaidyakhana, a government company, which produces ayurvedic products, there is a single person who has specialized on the subject.

\subsubsection{Marketing information}

A total of 20 informants thought that the lack of marketing information was the biggest issue in the NTFP sector. According to them, trade in NTFPs is not transparent and traders have great influence. Even though the materials are of good quality, harvesters do not have much say in pricing due to the un-transparent nature of NTFP trade. Traders do not want to share real prices and mostly work in isolation. There is a huge gap between road head traders, and harvesters, and harvesters get very little of the profit.

"Everyone is talking about poverty alleviation through trade on NTFPs. But the harvesters and FUGs do not know what price their products are sold in the market. They do not know about the market at the end of the value chain. Why isn't anyone trying to provide such information to them? If they get such information then it will increase their negotiation skills." (Informant \# 5, Traders and Harvesters sector) 
Further, they stressed that it affects the management of the sector and often the quality of materials is compromised. Getting quality materials becomes more difficult. Lack of market information and also lack of storage facilities makes harvesters unable to have a say on price. Further, even though Nepal has high species diversity, the volume of NTFPs is not sufficient which makes it difficult for traders so they have to rely on multiple sources from many areas.

"Nepal is rich in biodiversity. But it is not feasible to collect big volumes from any one place. This is affecting the traders." (Informant \# 4, Government sector)

\subsubsection{Capacity building and technology transfer}

The need for capacity building and technology transfer was seen as another big issue in the management of NTFP sector by 18 informants. They expressed that many people do not know what chemicals can be extracted from NTFPs. For this, institutional development is required so as to have techniques and tools. This can be done either by the private sector or by the government. Forest user groups who are managing the sector should be given an authoritative role and help in building their capacity. They need capacity building on sustainable harvest practices, management and enterprise development. There is a need for technology transfer. Since many times harvesters do not recognize all the species involved there is lot of adulteration and, as a result, they get low prices. This practice also affects the sustainable management of species since even unwanted species are collected. 
"There is a dire need of research and extension programmes. The process has been very slow. There are lots of people and organizations working in the NTFP sector who are also investing money. But all these initiatives have been rather scattered. If those works had been carried out in an integrated way then much could have been achieved." (Informant \# 5, Traders and Harvesters sector)

\subsubsection{Value addition and Enterprise development}

A total of 15 informants thought that there is a need for value addition and enterprise development for the management of the NTFP sector. There is not much processing and value addition being done on NTFPs that are collected and mostly are exported to India in raw form.

"Out of total collection, $90 \%$ goes to India as raw material. There should be enterprise development for the promotion of export. There is a lack of NTFP based enterprises in the country." (Informant \# 7, Government sector)

According to informants, value addition to the raw material would increase employment and generate more revenue. Further, most of them stressed that value addition at the local level would be particularly beneficial. Resource based enterprise development has not been initiated to a great detail in the country. There is a need for incentives such as subsidies for certain time periods, and market mechanisms should be developed. It is not easy for producers to enter the market as they cannot fulfill the formality of administrative processes. The formation of cooperatives by including 10-12 producers, 
forming a company and then marketing would give communities a hold on the trade of NTFPs. The current middlemen know exactly at which posts they have to bribe officials and easily transport materials. However, if harvesters choose to sell to the larger markets by themselves they face the difficulties. So forming a cooperative would help the harvesters and processors market their products.

\subsubsection{Administrative barriers}

The administrative barriers were cited as an issue by a total of 12 informants. The informants thought that the government's role should be that of a facilitator; instead there are instances where it is actually creating barriers for sustainable management and trade of NTFPs. This is not a conducive environment for enterprise development. If any trader wants to bring Chiraito (Swertia chirayita) from Ilam in Eastern Nepal to Kathmandu, he/she will likely have to give bribe in more than 20 places. In such a situation the trader finds it much easier to go to Kakarvitta on the border with India and sell it there.

"Recently, there was an incident in which there were hassles at 38 points while transporting one type of NTFP from Doti in west Nepal to Kakarvitta, a border town in east Nepal." (Informant \# 3, Non-government sector)

This shows that there is a lack of coordination between administrative bodies of the government and also with the other stakeholders. According to informants, administrative barriers are also found within the Community Forestry (CF) policy regarding NTFPs, even though there is a provision for FUGs to cultivate NTFPs in CFs. At times the district 
forest offices do not make it easy since they have to get the permission from them. The informants thought that the government is the biggest creator of barriers.

"Government should clarify it's role. It states it wants to play the role as facilitator which should also come into practice. It should facilitate the strengthening of national institutions such as those working on research and also the private sector." (Informant \# 2, Researcher)

Getting a permit from DFOs for the collection of NTFPs from government managed national forests can often be difficult. The requirement for IEE and EIA for larger quantities makes them available only to big traders. Farmers residing in remote and rural areas, for example in the far western district of Jumla, do not have the capacity to follow these procedures.

"It would be better if these types of assessments ie., IEE and EIA could be done by the district forest offices themselves so that there could be an environment for fair competition.." (Informant \# 5, Traders and Harvesters sector)

Further, the remoteness of the areas, where high value NTFPs are found, makes transportation of collected materials difficult. Many such districts in Nepal depend on occasional and undependable mountain flights for transportation. Permits are issued for 21 days which is not sufficient in such places. If the collector wants to renew the permit he/she needs to come down to district headquarters. 


\subsubsection{Royalty rates}

A total of 10 informants thought that the royalty rates for NTFPs should be revised. The present mechanism is not scientific, which is not helping for the sustainable management of the sector.

"Royalty rates are being determined on an ad hoc basis. They should be based on market prices at the local level and should be reviewed every 5 years. At times due to very high royalties, illegal trade is encouraged and this creates the environment for un-transparent trade." (Informant \# 7, Government sector)

For example there was a NRs. 20,000 royalty on $1 \mathrm{~kg}$. of Yarshagumba (Cordyceps sinensis); thus instead of paying the royalty harvesters traded illegally. In 2006 the rate was reduced to NRs. 10,000 which has made it possible for the government to collect at least some revenue. Many species are banned with little scientific reason which shows some degree of ambiguity on the listing of species.

"Nepal has very classical forest regulations and they are clumsy. The command and control policy mechanism is in place. Government is not able to regulate and they require all these permits." (Informant \# 6, Government sector)

\subsubsection{Unsustainable and Illegal harvest}

Unsustainable harvest and illegal harvest of NTFPs was also cited by 12 informants as major issue. According to informants, often collectors do not know what species are traded. Thus they tend to over harvest one or a few species, which poses threats to these 
species while many other tradable species are not collected. Often the harvesting practices are unsustainable due to a lack of awareness and information. Also there are instances of early harvest without leaving sufficient stock for regeneration of many NTFPs due to competition. Lack of market information too leads to these situations. Further, lack of stock baseline poses a big question on permits issued by DFOs which could impact negatively the resource base of NTFPs. Many informants stated that illegal harvest of many high value NTFPs is quite prevalent. For example Maikokila, Kutki and Jatamansi are traded to China from the northern borders of Nepal. Even though these species have been banned by the government, trade has not stopped.

"Species are banned but we do not know the real reason for banning. This affects the NTFP trade. It has been difficult to operationalize legal producers. Further, the trade is dependent on the Indian market so they are not getting the real price either.” (Informant \# 1, Government sector)

\subsubsection{Cultivation on private land}

A total of 6 informants thought that policies should clearly be able to disaggregate trading operation between the NTFP species that are cultivated and those that are collected from the wild.

"The government collects royalties even on materials that are cultivated on private lands." (Informant \# 5, Traders and Harvesters sector)

For example Chiraito (Sweria chirayita) is in the Red data book of IUCN so it cannot be exported easily. Jatamansi (Nardostachys grandiflora) is a banned species in Nepal and 
it cannot be exported in raw form if collected from the wild. However, it can be exported if cultivated, but there is no certification process currently in the country. There is no policy in place for species that are cultivated.

\subsubsection{Lack of focus}

A total of 5 respondents thought that there is lack of focus on the management of NTFP sector. They thought that there is not sufficient focus being given to potential revenues possible from various NTFPs and many DFOs have not realized this potential. They are still thought to be a subsistence product with little earning source.

"The concerned authorities have not given much attention to the management of the NTFP sector. The authorities are not responsible but they think they are managers. Without investing they think it will bring dollars." (Informant \# 4, Researcher)

\subsection{Impact of the Maoist insurgency on the NTFP sector}

High value NTFPs in Nepal are mostly found in remote areas and such areas were mostly occupied by Maoist insurgents until late 2006. The following views were expressed by various informants during the discussion. It is said that NTFPs have been a major source of funding for the insurgency and the sale of high value species as Yarshagumba (Cordyceps sinensis) has generated millions of dollars for them. Local harvesters and FUGs were affected the most and their interest in this sector has declined. Many had to pay royalties to the government as well as the Maoists who were residing in national 
forests. The Maoists had imposed their own taxation systems. On the other hand the government was also affected as it could not generate revenues due to the absence of administrative bodies in localities where Maoists were present. The regulatory bodies of the government were defunct, which may have increased illegal trade. At the same time the amount of funds generated by the Maoists show that if the government is efficient, it could generate much more revenue than what it had been.

"It is said that the Maoists generated US \$25 millions within 3 months from taxation on Yarshagumba in the western part of Nepal. It shows that if there is good governance and the government is vigilant enough a lot of revenue can be generated." (Informant \# 7, Non-government sector)

This could be a good lesson for the government of Nepal for the future. However, private interests such as Dabur Nepal constantly faced problems and reached the point where it had to close its nursery facilities several times. At the same time a few respondents had the view that the presence of Maoists in forests has actually helped conservation, as harvesters were not collecting NTFPs due to security reasons. This would have had adverse impacts on the livelihoods of people.

\subsection{Domestication and cultivation of NTFPs}

Regarding the domestication and cultivation of NTFPs, which the NTFP policy 2004 states to promote, the following information came out during the discussions. There have been few instances of domestication and cultivation of NTFP species that are of high 
value and being depleted in the wild. Often these were initiated through Integrated Conservation and Development Projects of quite a few INGOs. However, there is a major policy gap on the prospect of proposed domestication and cultivation of NTFPs. There is lack of technology and resources to develop these initiatives. Not all of the 12 prioritized species can be cultivated. The research done to date is not sufficient and Nepal cannot go into large scale cultivation anytime soon.

"There is a need of focused research on these 12 species. Techniques need to be developed, which has not happened yet. There is a need for more research trials. But then there is lack of budget in the Department of Plant Resources for it to carry out the research." (Informant \# 7, Government sector)

Further, informants stated that we have to bear in mind the agro-eco climatic zone of the species as it affects its alkaloid properties. So it would be better to focus on managing what is collected from the wild. Then there are issues of certification since many of these prioritized species are banned in some form. Certification is not within the reach and financial capacity of local FUGs and producers. The formants thought that there are many ambiguities in the policies. Further there should be a known market before cultivation is started to provide incentives for cultivators.

\subsection{The size of production and export}

According to most of the informants, available data do not show the actual amount of harvest, production and export of NTFP species in Nepal. Whatever data are there are 
scattered. Customs office data just generalize NTFPs and do not categorize them. Plant quarantine certificates are required to export to India and this could be another good source of data. However, they do not specify much about species. There is lot of informal trade encouraged mainly due to lengthy administrative processes of the government. The administration is not strong enough and can be easily bribed. It is estimated that the total trade amounts to US\$ $60-100$ million, but this estimate varies widely. Some say that $40 \%$ of the volume is not recorded by the government due to illegal trade. Others claimed that $80 \%$ is illegal. The data vary even between the trade center and the Government. Many respondents expressed that no one knows the actual volume of NTFPs that is in trade in Nepal.

"There are different estimates of the total production and export of NTFPs in Nepal. The revenue collection, only, should not be the criteria. Government should do gross estimation." (Informant \# 11, Non-government sector)

\subsection{The Banned species list and CITES}

Conservation of important species is also necessary for the management of NTFP sector, thus the views regarding the government regulations are relevant. Most of the interviewees stressed that the list of species banned by the Forest Act needs updating based on scientific research (Figure 3). A total of 22 informants thought that it needs updating, 2 thought it did not need updating while 4 informants did not express an opinion. According to informants, in-depth research is required before any species is either listed or de-listed. 


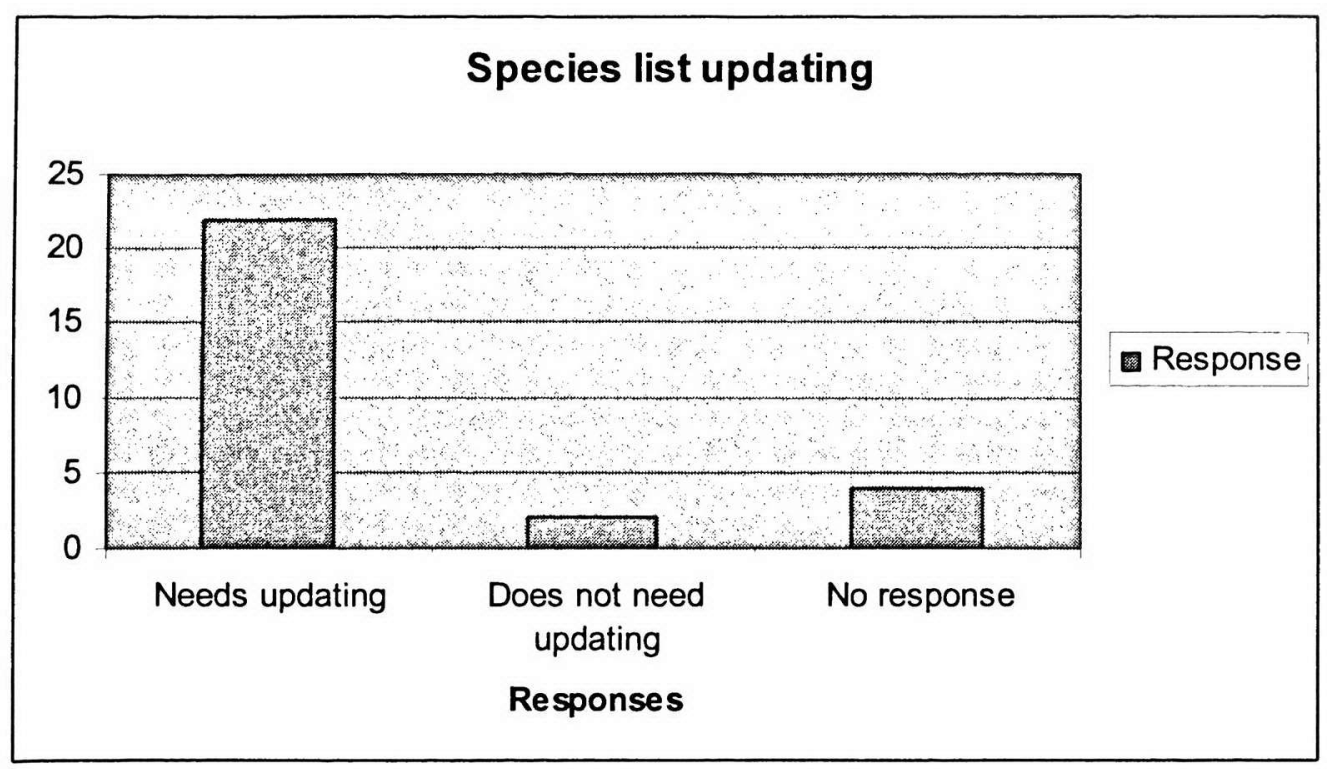

Figure 3: The species list of Forest Act and CITES - Interview response

The present list does not match the draft Rare (Endangered) Wildlife and Plants Trade Control Act list, national legislation for CITES implementation in Nepal. There is ambiguity on species identification. The informants further stated that the government does not show initiative in updating the list and whatever is done is usually through pressure from other stakeholders. It was recently discovered that the Picrorhiza scrophulariiflora (Kutki) that was banned in Nepal was not the same species that is banned under CITES. Some thought that illegal trade is going on because of the banning of the species. There was an instance where the Parsa district forest office had seized 94 $\mathrm{kg}$ of Dactylorhiza hatagirea (Panchaule) and this is a banned species. The DFO then contacted Singhadarbar Vaidyakhana and offered to hand over the plants to their production unit. There are doubtlessly many more instances of illegal trade that are not discovered. 
According to some informants, , the entire Himalayan region should be considered as one entity for CITES implementation. CITES is limited to nations but most resources go beyond national boundaries and the Indo-Nepalese border is open. Implementation of such treaties thus needs a regional strategy. Nepal has been the transit point for several species listed by CITES. There were several instances where NTFPs were transited from India through Nepal to China and from China to India. There was an instance where the northern check post between Nepal and China at Tatopani seized such materials. But then a question arises as to how it is possible for the trader not to be caught before reaching all the way north from the southern border between Nepal and India.

"We can get a picture of the situation if we look into 2-3 year old such seizures and legal cases. The main reason is that customs officers and narcotic police are not trained to identify NTFPs." (Informant \# 4, Non-government sector)

\subsection{Policy implementation process}

Nepal is fortunate to have a separate policy for NTFPs but there are no implementation plans or regulations formulated till date.

"Developing countries have little capacity to implement and execute policy." (Informant \# 6, Government sector)

There is a need for administrative expansion and simplification. Administrative processes must be conducive to the objective of the policy. The policy should be adaptive as well, as more becomes known about the abundance of selected species. Some suggested that 
instead of having a separate strategy it should be incorporated in existing forest policies. But others expressed that this would not work because the DoF is focused on timber so the NTFP sector should have a separate implementation strategy.

The Herbs and NTFP Coordination Committee is dependent on the resources of other organizations to run its office. It clearly lacks funding and human resource. Practically, at present, $\mathrm{HNCC}$ is run by a single officer under the guidance of the Director General of DPR and the MFSC. The Committee meets only once a year although there is a provision that meetings can be called any time as required. The advisory and general meetings are also there when the concerned authorities and stakeholders are invited. However, there is dissatisfaction from several stakeholders who think that not all stakeholders are represented sufficiently. Specifically NGOs and private bodies have very little representation on the committee. Some informants also recommended during the discussions that HNCC should be an autonomous body for it to work effectively.

"HNCC needs continuous support from the government. The support from the private sector and donors is also required. The expectations for HNCC have increased but there is a clear lack of budget and manpower. HNCC should be a strong organization to promote the NTFP sector in Nepal." (Informant \# 7, Government sector) 
Further, many respondents said that in the current political situation makes it difficult to think about making progress in the implementation process.

"Once the government of Nepal settles from the current crisis of the political situation, NTFPs will not be top priority. Government has to focus on economic, political and socio-cultural aspects and it will take some time for the NTFP sector to get focus. It will come under long term vision and planning." (Informant \# 10, Non-government sector) 


\section{DISCUSSION}

Research capacity in Nepal is still in a rudimentary state and appropriate resource assessment methodology, monitoring procedures, and protection measures are not well developed. There is a need for ecological studies of NTFPs and their habitats to better understand and implement management strategies required to develop NTFP sector in Nepal, a concern which was expressed by most informants. Adaptive management approaches prevalent in traditional knowledge of management of NTFPs could be taken into account when designing scientific studies. Recent studies have shown that local knowledge and practices have certain similarities to complex adaptive systems, to deal with uncertainty and to respond to ecosystem change (Subedi, 1999). Scientific research based on local knowledge and practices would help in forming relevant management strategies (Ghimire et. al. 2004). Traditional knowledge of rare plants can help the identification, management, protection and recovery of habitats or species (Donovan and Puri, 2004) and can be taken into consideration for guidelines for research (Chaudhary, 2000).

In addition, there should be inventories and life history studies of the harvested species within various existing management practices. Then only it would be proper to draw conclusions on actual impacts of commercial harvest of NTFPs from national forests and it would help managers to make decisions. A strong and participatory monitoring system is essential to sustain resource conservation, develop management plans, track and manage changes, measure performance, make strategic decisions, and overall, develop 
adaptive enterprises. The policy promotes small scale enterprises based on NTFPs at the local level. However, a major observation is that monitoring enterprises on natural products is a weak link in the region (Karki and Nagpal, 2006). The commercial extraction of NTFPs to help in the livelihoods of people is being promoted by the new policy. But the basic assumption that commercial extraction of NTFPs has little or no ecological impact on forests is not true (Peters, 1996). So care must be taken before implementing such policies and they should be based on studies and past experiences.

Management knowledge and techniques have not been well developed for NTFPs in Nepal. The NTFP policy attempts to promote sustainable development through conservation and promotion of NTFPs in the wild. However, the species specific information both for in-situ and ex-situ conservation is lacking. In-situ conservation is the management and protection of species in natural habitat in various protected areas while ex-situ conservation implies the cultivation and management of the species on private lands. Often, unscientific harvesting, where the full ecological implications are not taken into consideration, may lead to possible extirpation of many species. Many commercial species, specifically herbs, are extracted as whole plants and for many, the underground parts are extracted. For many species where aerial parts are used it is mostly for bark. In such a case, indigenous knowledge and traditional skills limited to subsistence use levels may not be sufficient for management at larger economic scales and would need to be supplemented with the best available science. Science could determine impacts to populations if individuals are extracted for commercial scale from the available resource base. Due to the harvest of NTFPs, ecological processes may be affected at many levels, 
from individual to populations and to communities and ecosystems (Ticktin, 2004). The ecosystem structure may change which may have an effect on function. Traditionally knowledge had been sufficient for subsistence use. But for ever growing large commercial scale harvests it may not be sufficient. Thus life histories and plant associations should be studied for species that are heavily harvested, or in demand on a commercial scale, so that sustainable management practices can be applied. It would be appropriate to start the work from the list of plants that have been prioritized for research and development. Forests and plant resources need a new research thrust to bring about a synergy between biodiversity and biotechnology. Biodiversity management in Nepal should have strong linkages with modern technologies for value addition to products by extracting chemicals and making various medicinal and aromatic products from NTFPs. The research initiatives of DPR should be tapped fully for further growth and management of this sector. They should not be limited to laboratory tests; rather, the government should consider implementing knowledge in the field.

For the promotion of NTFPs at commercial scales, market information is very important to help local and national economies. However, due to the lack of an organized marketing information system, NTFP traders have no choice but to export products to India at low prices. The existing market structure is imperfect with regard to infrastructure, nature of competition, demand and supply characteristics (ABTRACO, 2004). Trade flows are susceptible to changes in market requirements (Arnold and Ruiz-Perez, 2005). It is imperative to develop a market information network in this region for widening markets to help the economy of Nepal. ANSAB/USAID (2005) had reported that about 160 
species are in trade which generated about Rs. 2.5 billion in 2002 (US\$ 35 million) whereas the lost opportunities are estimated by the 42 million dollars every year. Among medicinal plants more than 100 are in trade and 21 of them are high value species. Recently, sales of NTFPs and MAPs are increasing, including exports to India (ADB, 2004 ) and over $90 \%$ of trade is still with India (Edwards, 1996a; Malla et.al. 1999). So it would be better if the NTFP market to India is focused rather than other international markets. Also, Nepal can provide a large variety of products rather than large quantities of a product. The government should look into regulating this market by taking into consideration these factors for overall management of the sector. With the initiation of ANSAB and FECOFUN, a list of the market prices at various urban markets in Nepal and India of major NTFPs that are in trade is brought out every month. Such initiations are good and should be promoted but then the information should reach to the harvesters at the local level which is stated in the NTFP policy. But at present the information is available mostly at the central level.

Value addition to NTFPs could help greatly the national economy. Small scale valueadding activities run by NTFP harvesters, user groups or co-operatives would be of relevance to rural development (Edwards, 1996a). Very small amounts of NTFPs collected are processed in the country by a few processing industries or cottage industries, mostly established recently. Regarding the domestication of plants in community forestry, establishment of forest based enterprises is not allowed within $3 \mathrm{~km}$ in hilly areas and $5 \mathrm{~km}$ in the Terai from community forests (Ojha, 2000). This is a great disincentive for the FUGs that would be interested in enterprise development. These 
types of policy hurdles and control oriented provisions without adequate implementation capacity leads to unsustainable management and encourages illegal harvest and trade of NTFPs.

FECOFUN has been working to facilitate the process between FUGs and the government. FUGs are legislatively-recognized self governing autonomous entities that are entrusted with the management, control, utilization and sale of community forest resources by following operational plans (Subedi, 1999). However, technical and management guidance is required for institutional strengthening of these groups. Government and NGOs need to take a lead role in empowering these groups for the paradigm shift from subsistence to enterprise-oriented management. Available skills are not enough for the management of resources at commercial scales. The focus should shift to capacity building of these institutions towards practicing techniques of managing NTFPs in community forests (Pandit and Thapa, 2003) and cultivating on private lands on large scales, which would put less stress on natural forests. However, suitable institutions and interventions have to be highly site specific since there are considerable regional variations in the nature of NTFP production and trade (Edwards, 1996b).

The research results showed that there are many administrative barriers in the management of NTFP sector. There is little shared understanding of the objectives of policies regarding NTFPs in the forest administration where District Forest Office staff mostly view the purpose of permits to be a source of royalty rather than monitoring (Larsen et. al., 2005). There is little supervision or control on collection and there is no 
rational basis for issuing permits for different areas where forest officials often have poor knowledge of basic plant identification (Subedi, 1999). The NTFP policy does not mention anything about the permitting process for the NTFPs that are extracted from government managed national forests. Inventory of resources before issuing permits by the government is required to ensure that the NTFPs are not depleted. Conservation of NTFPs requires identification of optimal harvest regimes, accurate estimation of maximum harvest limits and the implementation of these limits (Ticktin et.al. 2002). The sustainable management of natural resources requires sound knowledge of ecology, spatial distribution and abundance which can be obtained from various sources as indigenous knowledge and scientific forest inventories (Bih, 2006). Methods of assessment and sustainable harvesting should be site and product specific (Ojha and Bhattarai, 2003). For this, there is a need for experts with scientific and technical knowledge on NTFPs in extension programmes. At present, harvesters can collect NTFPs from the wild after paying fixed royalties to the government. There is a need to assess the annual harvestable quantity from any particular area for NTFPs but this seems a difficult proposition especially with the lack of expertise. Further, combining forest inventory with NTFP assessment could be technically feasible but budget may be a constraint for application over large area (Kleinn et. al. 1996). In such a situation with no possibility of scientific studies at such levels in the near future, great responsibility lies on the DFOs who should take great care before issuing permits. At the same time, royalties collected from trade of NTFPs are a great source of revenue for the Government of Nepal. However, trade has faced various problems. Local harvesters get a meager share of profits whereas most are taken by middlemen who trade in international markets (Ojha, 
2000; BDS-MAPs, 2004; Maraseni, 2004). In addition, a large part of revenue is lost through illegal trade in the country (Subedi, 1999; Subedi 2006). Until now, the government has not been able to regulate international trade of NTFPs completely due to a lack of specific policies to deal with the trade, and the NTFP policy would facilitate this process through the intervention of private sector.

There is a lack of incentives in government policies and programmes for people to adhere to sustainable and legal methods for trade of NTFPs. Proper interventions from the government policies and programmes and facilitation from the NGO sector would be helpful to promote healthy and legal pathways for this sector. Domestication and cultivation of NTFPs on private and community lands, development of small enterprises and selling to international markets present very good prospects to meet the dual goals of conservation and livelihood enhancement. However, relevant legal mechanisms and proper scientific and management techniques are needed. The NTFP policy attempts to facilitate the certification process, but does not clearly state information about the certification of species that are cultivated which are otherwise banned under the Forest Act, 1993. The Forest Stewardship Council forest management certification process implemented in 2 districts should be expanded in other areas of the country. Specifically, there is a need to develop quality control, certification, and standardization of prized Nepalese herbs (ANSAB/USAID, 2005). The certification of NTFPs can provide higher prices for producers and also help in monitoring so as to manage the sector (Walter et. al. 2003). Further, greater investment is needed to access diversity of resources through transport and communication networks in order to promote agro-industries, forest based 
industries and NTFP processing industries at scales that are appropriate for sustainable harvest (Shrestha, 2001).

In addition, the government has to deal with plants that are listed under the Forest Act and plants that are listed under the Rare (Endangered) Wildlife and Plants Trade Control Act and restrictions are varied on these species. The two lists have different regulations which require integration between departments and programmes to regulate the sector. The NTFP policy does not mention anything about these lists, however they are very important since many of the banned species are high value NTFP species that are often traded illegally. The policy should clearly mention about management of such species. The research result showed that the lists clearly need updating and should be based more on scientific studies. The NTFP policy and other related policies require dealing with both conservation of resources and sustainable use and trade in the sector. Further, there is a need to categorize plants. There are three distinct but mutually non-exclusive types of NTFPs, i.e., locally used or traded for subsistence, commercially traded, and those with potential for trade. The latter two have higher potential for contribution to the cash economy (Subedi, 1999). Further, understanding the behavior of people within the context of income generation from NTFPs is crucial for policy formulation (Gopalakrishnan et. al. 2005).

NTFPs are mostly collected from government managed national forests in Nepal which are open-access due to the lack of regulatory bodies in remote areas where the resources are at risk of being depleted. The collectors have a bundle of rights and are authorized 
users with access and withdrawal rights for subsistence use (Ostrum, 2003). With the promotion of commercial extraction by NTFP policy, Hardin, 1968's theory of "the tragedy of commons" may be applicable if the government does not facilitate the process. Government forests in northern parts of the country are rich in NTFPs, mostly medicinal plants, which are smuggled to India and China. Illegal activities are basically due to the lack of ownership of the land by the collectors in government managed forests (ICIMOD, 2004). Promotion of NTFP harvest and management in community and leasehold forests would work better since the users have the management rights over these forests. With the success of Community Forestry in the country, there is the prospect of handing over government forests to user groups for management and sustainable use of forests, specifically areas rich in NTFPs but there is limited experience with management of NTFPs under community forestry schemes (Olsen and Larsen, 2003). Further, the government is reluctant to hand over forests rich in NTFPs to community forestry user groups for fear of losing valuable assets (Malla et. al. 1999; Rawal and Shrestha, 2006). In addition, even if harvesters owned the land, with a large cross-border market for NTFPs and in the absence of proper regulatory mechanisms, incentives to act illegally would still exist. Nepal has been hard hit by the Maoist insurgency for more than a decade, which is a major threat towards effective management of natural resources (Baral and Heinen, 2006). The government is not able to implement conservation policies to a fuller extent as many parts of the country were under Maoist control from 1996 until 2006. 
The initiatives to cultivate NTFPs on private and community forests would reduce harvesting pressures on government managed national forests. For this, research work done by the DPR would help in choosing species to be domesticated as well processed to add value. In that case there would be a low administrative burden of regulations as only those species which cannot be cultivated would need management. However, research work that is done to date is not sufficient to promote the cultivation of NTFPs on a large scale. Further, it is hard to predict the long-term consequences of NTFP cultivation (Trauernicht et. al., 2006). There is a concern that the cultivated NTFPs may not have the same important chemicals found in species that are collected from the wild. The experience on cultivation of some NTFPs in the region is at an early stage (Van de Kop and Alam, 2006)

Collectors have to be trained about different aspects of sustainable ways to collect different NTFPs available in their area. Collectors, especially the younger generation, should know and learn how to collect NTFPs, e.g. the right time to collect, the right size and technique to harvest without destructing the habitat, leaving behind enough resources so that the following season there would be enough materials for harvest, maintaining quality and observing proper post harvesting techniques, transportation, etc; use of updated market information; and knowing prevalent legal processes of collection and transportation. These are all areas of support that INGOs and NGOs could effectively provide to promote the NTFP sector. 
Country-side ecology is very much dependent upon the relationship between farms and forests. With the continued growth of the human population of Nepal, there are increasing pressures on natural resources for food and agricultural products. NTFPs supplement diets and household income, especially during particular seasons of the year, and help in medicinal requirements. For generations, NTFPs have been a major source of income in remote areas where most people are poor. With subsistence livelihoods, people try to meet everyday needs by trading NTFPs, which are mostly collected from national forests and sold in local markets or to the traders who ultimately sell to international markets. Even though the NTFP policy attempts to promote NTFPs in international markets, care should be taken so that over-enthusiasm may not have adverse impacts on resources in the wild. There is increasing global market demand for NTFPs with the growth of herbal and ayurvedic medicines. With the increased commercial demand for forest products, first output increases, then as quality and quantity decline from wild sources, prices rise (Arnold and Ruiz-Perez, 2005). With the rise in price, buyers and traders induce harvesters to collect more NTFPs. In turn, harvesters increase extraction rates, resulting in overexploitation of NTFP resources (Neuman and Hirsch, 2000). Thus, increasing market demand accelerates rampant collection from the sources specifically which are open access areas in remote regions where very little monitoring is done by forestry officials (Malla et al., 1999). In the presence of poverty and subsistence, community members tend to compete with each other to get a better share of the market and once prevalent social values for conservation are set aside, indigenous knowledge of management alone would not be sufficient. As a result, sustainable production of many valuable NTFPs is seriously affected by over-harvesting and premature harvesting. 
Market demand is mostly selective and works against the ecological objectives of conserving the profile of biological diversity present in pristine forests (Arnold and RuizPerez, 2005). The NTFP certification process that has been initiated can help in accessing new markets if market demand is there for the species (Shanley et. al. 2005; Pierce, 1999). There is potential for domestication and cultivation to generate products that are in demand for export with simplified administrative processes and the NTFP policy would facilitate this process.

Community based conservation approaches through community forestry seem a viable option for Nepal both for livelihoods and conservation of the NTFP sector (YildizThomas and Karki, 2002), however, effective implementation is complex and difficult (Kellert et. al. 2000). There have been many initiatives in this direction from various organizations and institutions. Even though many projects and programmes in different sectors have tried to develop the NTFP sector mostly through participatory models, limited property rights in addition to subsistence orientation in these models have neither been able to improve livelihoods of people nor conserve resources. Gaps and inconsistencies in such programmes loom large on the horizon. Forestry programmes have been oriented towards meeting the aspirations and needs of people; however, significant changes in approach are required to promote conservation and sustainable management of NTFPs (Larsen et. al. 2005). Even though Nepal has been progressive in conservation of natural resources in the country, it has not been able to successfully meet its conservation goals for NTFPs. The reason for slow progress, in addition to growing poverty and insurgency, is the lack of integration between the various policies, 
departments and programmes of the government and NGOs. The NTFP related policies should compliment each other. There is a need for more coordination between the Departments of Forests and the Department of Plant Resources. Further, various sectors, i.e., government, non-government and private, should come together to work for the management of NTFPs in Nepal. The NTFP policy promotes the NGOs and the private sector in NTFP management which should be a priority for the implementation of the policy.

Even though Nepal has been progressive in conservation and management initiatives, there is still a long way to go (Heinen and Chapagain, 2002). There is a need for significant changes in approach to promote conservation and sustainable management of NTFPs. In their stakeholder assessment study in Nepal, Larsen, et. al. (2005) showed that the exclusion of harvesters from the policy formation process, and the current collection permits and bans, do not strongly affect resource utilization. NTFP policy formulation had been a participatory process and it has focused on harvesters and collectors of NTFPs at the local level. Communities have indigenous knowledge of forest and NTFP management. However, the market drivers for NTFPs at present have led to changes in social and behavioral factors and communities tend to compete with each other to get better market share. As a result, the resources are depleted. This competitive behavior should be diverted towards community forestry and private plantations where social values could work as an incentive to manage resources in a sustainable manner in the wild. Sustainable forestry stands a better chance of success if conservation oriented forest management practices can be implemented without significantly affecting the interests of 
local stakeholders who highly depend on NTFPs for food and income (Mahapatra and Tewari, 2005).

Regarding NTFP use, it is unrealistic to assume that developmental and conservation interests coincide completely; and the management of the sector would be easier and effective if it focuses on the areas the two coincide to achieve the goals (Arnold and Ruiz-Perez, 2005). Still much needs to be done to find areas of conflict between the two and work for better management strategies. Most important is the implementation of the NTFP policy for the management of the sector and Nepal is fortunate to have a separate policy for NTFPs. But there should be an implementation strategy for the success of this policy. To date there are no implementation plans or regulation in place even after 3 years since the NTFP policy was adopted in 2004. Further, there is a need for administrative expansion. The administrative processes should be conducive to the objective of the policy. The policy should be adaptive in nature and the policy cycle framework would be relevant for the process (Hoberg, 2001). There is a need for an NTFP implementation strategy that would complement other NTFP related policies. Further, HNCC, which has the responsibility of facilitating this process, needs strengthening in human and financial resources for it to perform it effectively. Inclusion of more stakeholders on the committee is needed for proper formulation of a strategy and for effective implementation. The political situation in the country plays a major role in effective implementation of any policy and Nepal is at present going through political crisis. Thus it could take a while for the formulation and implementation of strategy for the NTFP policy. 


\section{CONCLUSIONS}

The NTFP sector in Nepal presents options for conservation linked development opportunities. Being a signatory to CBD, sustainable management of the NTFP sector should be a primary concern for Nepal. With the adoption of the Herbs and NTFP Development Policy, 2004, Nepal is taking a path towards this goal. However, the decade long Maoist insurgency kept most of the sector on the back seat and the NTFP sector was also greatly affected. Even though no implementation plan has yet been developed, the concerned departments, ie., the Department of Forests and the Department of Plant Resources, have been promoting elements of the policy in their programmes. The formation of the Herbs and NTFP Coordination Council is also a positive initiative although it needs strengthening so that it can facilitate implementation policies.

This research showed that there are many issues of concern related to the management of the NTFP sector in Nepal. Since the sector is increasingly important for income generation with the demand for many NTFP species in international market increasing, management of the NTFP sector in Nepal is very much related to management issues in trade of NTFPs. The most important issue is the need for inventory and research on NTFP species in Nepal. There is lack of marketing information which makes the sector non-transparent and, in some cases, illegal. Harvesters need capacity building and there is a need for technology transfer so that there are sustainable harvesting practices. The prospect of value addition to NTFPs, rather than exporting in raw form only, and enterprise development are also required so as to help in the economy in general. The 
government should make administrative processes conducive to what the NTFP policy has tried to achieve. This includes scientific methods for determining royalty rates and issuing permits. Unsustainable and illegal harvest is another major issue which is often aggravated due to administrative barriers. Further, the prospect of domestication and cultivation of NTFPs seems to be a good proposition. However, for a country like Nepal, it may be difficult as it requires scientific research and proper legal mechanisms to be effective.

There are great challenges to manage this sector especially as the magnitude of production and export volumes are not known. With the lack of such data, it becomes difficult to implement national level programmes for sustainable management of the NTFP sector. There are few data on species listed on the Forest Act, 1993, Forest Regulation, 1995 and the Rare (Endangered) Wildlife and Plants Trade Control Act, 2000 (draft). The banning of species should be based on scientific studies and needs constant updating. Most importantly, for effective implementation of the NTFP policy, there should be a strategy and plans in place. There should be a separate implementation strategy which should include the provisions of other policies and complement the related policies such as the Forest Act and CITES legislation. All the concerned departments and programmes should coordinate and come forward to promote the NTFP sector towards sustainable management. The Herbs and NTFP Development Policy 2004 seems to be more of an incentive based policy that has focused on the sustainable development at the local level. But care must be taken in implementation so that conservation goals do not become secondary. Further, there is an understanding that two departments - the 
Department of Forests and the Department of Plant Resources, under the Ministry of Forests and Soil Conservation, would implement the policy. However, the policy should clearly specify the roles of the departments which are very important for effective implementation.

\subsection{Implications of the research}

It is expected that the major implication of this research would be future policy directions for the effective implementation of policies regarding NTFPs and other plant species important in trade in Nepal. Most importantly the research findings can help in the formulation of the implementation strategy and plan for the NTFP policy. Further, the opinions of policies relating to NTFPs from different stakeholders, ranging from regulatory bodies to implementers and other organizations that are affected by the policies provide a starting point for the coordination of different sectors and integration across programmes. This will help the government to develop the NTFP sector along the stated mission of conservation and sustainable development, as articulated in CBD and also help towards its obligations to CITES. 


\section{REFERENCES}

ABTRACO. 2004. A Study Report on Trade Pattern of Non-Timber Forest Products (NTFPs) in Jumla, Surkhet and Nepalgunj: Appropriate Policy Measures for Business Support and Trade enhancement. Submitted to Agro-Enterprise Center (AEC)/Federation of Nepalese Chambers of Commerce and Industry (FNCCI). Kathmandu, Nepal.

ADB. 2004. Country Environmental Analysis for Nepal. Asian Development Bank.

Anil, C.N. and Kerkhoff, E. 2005. Corporate Sector Partnership for NTFP Development in Nepal. In Biodiversity and Livelihood in the Hindu Kush-Himalayan Region: ICIMOD Newsletter. No. 45.

ANSAB. 2003. Non-Timber Forest Products in Nepal National Policy workshop. A workshop proceeding. ANSAB, Kathmanu, Nepal.

ANSAB/USAID. 2005. Nepal NTFP Alliance. Final report: Certification and Sustainable Marketing of Non-timber Forest Products (NTFP) - Private Public Alliance (PPA). USAID, Nepal.

Arnold, J.E.M. and Ruiz-Perez, M. 2005. Can Non-timber Forest Products Match Tropical Forest Conservation and Development Objectives? In Sayer, J. (ed.) The Earthscan Reader in Forestry and Development. Earthscan, London.

Ashton, M.S., Gunatilleka, C.V.S., Singhakumara, B.M.P. and Gunatilleka, I.A.U.N. 2001. Restoration Pathways for Rain Forest in Southwest Srilanka: a review of concepts and models. In Forest Ecology and Management 154 (2001) 409-430.

Ausband, L. 2006. Qualitative Research and Quilting: Advice for Novice Researchers In The Qualitative Report, Volume 11, No. 4:764-770. http://www.nova.edu/ssss/QR/QR11-4/ausband.pdf

Babu, S.C. 2000. Capacity Strengthening in Environmental and Natural Resource Policy Analysis: Meeting the Changing Needs. In Journal of Environmental Management 59: 71-86.

Baral, N. and Heinen, J.T. 2006. The Maoist People's War and Conservation in Nepal. In Politics and the Life Sciences 24 (1-2): 2-11.

BDS-MAPs. 2004. Final Report on Workshop on NTFPs Marketing Challenges, Issues and Recommendations for Future Strategy, Kathmandu, Nepal.

Belcher, B.M. 2003. What isn't an NTFP? In International Forestry Review 5(2): 161 168. 
Belcher, B., Ruiz-Perez, M. and Achdiawan, R. 2005. Global Patterns and Trends in the Use and Management of Commercial NTFPs: Implications for Livelihoods and Conservation. In World Development 33(9): 1435-1452.

Bennett, B.C. 2002. Forest Products and Traditional Peoples: Economic, Biological and Cultural Considerations. In Natural Resources Forum 26: 293-301.

Bernard, R.H. 2002. Research Methods in Anthropology: Qualitative and Quantitative Approaches. Third Edition. Altamira Press.

Bih, F. 2006. Assessment Methods for Non-timber Forest Products in Off-reserve Forests: Case study of Goaso district, Ghana. A Ph. D. Dissertation. The Faculty of Forestry and Environmental Sciences, University of Freiburg, Germany.

CECI. 2006. Synthesis of Seminar Presentations and Discussions during First national Trade Show and Seminar on Herbs, Herbal Products and Spices, 12-14 November 2005, Nepalgung. Sahakarya Project, Canadian Center for International Studies and Cooperation, Nepal.

Chaudhary, R.P. 2000. Forest Conservation and Environmental Management in Nepal: a review. In Biodiversity and Conservation 9:1235-1260.

Chettri, N and Sharma, E. 2006. Prospective for Developing a Transboundary Conservation Landscape in the Eastern Himalayas. In McNeely, J. A.; McCarthy, T. M.; Smith, A.; Olsvig-Whittaker, L.; Wikramanayake, E. D. (eds) Conservation Biology in Asia. Society for Conservation Biology Asia Section and Resources Himalaya Foundation, Resources Himalaya Foundation, Kathmandu. pp 21-44.

de Beer, J.H. and McDermott, M. 1989. The Economic Value of Non-Timber Forest Products in South East Asia. The Netherlands Committee for IUCN, Amsterdam.

Donovan, D.G. and Puri, R.K. 2004. Learning from Traditional Knowledge of Nontimber Forest Products: Penan Benalui and the Autecology of Aquilaria in Indonesian Borneo. In Ecology and Society 9(3): 3.

DPR/MFSC. 2005. Annual Report 2061/62 B.S. Department of Plant Resources, Ministry of Forests and Soil Conservation, Kathmandu, Nepal.

Edwards, D.M. 1996a. Non-Timber Forest Products in Nepal: Aspects of the Trade in Medicinal and Aromatic Plants. FORESC Monograph 1/96, Forest Research and Survey Center, Ministry of Forests and Soil Conservation, Kathmandu, Nepal.

Edwards, D. M. 1996b. The Trade in Non-timber Forest Products from Nepal. In Mountain Research and Development 16(4): 385-394. 
Ghimire, S., McKey, D., Aumeeruddy-Thomas, Y. 2004. Heterogeneity in ethno ecological knowledge and management of medicinal plants in the Himalayas of Nepal: implications for conservation. In Ecology and Society. 9(3): 6.

Gopalakrishnan, C., Wickramasinghe, W.A.R, Gunatilake, H.M. and Illukpitiya, P. 2005. Estimating the demand for non-timber forest products among rural communities: a case study from the Sinharaja Rain Forest region, Sri Lanka. In Agroforestry Systems 65:13-22.

Hardin. G. 1968. The Tragedy of the Commons. In Science 162:1243-1248.

Harini, N., Karmacharya, M. and Karna, B. 2005. Nagendra, H., Karmacharya, M. and Karna, B. 2005. Evaluating forest management in Nepal: views across space and time. In Ecology and Society 10(1): 24.

Heinen, J.T. and Mehta. J.N. 2000. Emerging Issues in Legal and Procedural Aspects of Buffer Zone Management with Case Studies From Nepal. In Journal of Environment and Development 9(1): 45-67.

Heinen, J.T. and Chapagain, D. P. 2002. On the Expansion of Species Protection in Nepal: Advances and Pitfalls of New Efforts to Implement and Comply with CITES. In Journal of International Wildlife Law and Policy 5:235-250.

HMGN. 2000. Rare (Endangered) Wildlife and Plants Trade Control Act, 2057 (2000). His Majesty's Government of Nepal. A draft document.

HMGN. 2004. Herbs and Non timber forest products development policy, 2061. His Majesty's Government of Nepal, Ministry of Forests and Soil Conservation, Herbs and NTFPs Coordination Committee, Kathmandu, Nepal. A document in Nepali.

HMGN/MFSC. 2002. Nepal Biodiversity Strategy. Ministry of Forests and Soil Conservation, His Majesty's Government of Nepal, Kathmandu, Nepal.

HMGN/USAID.1995. Forest Act 2049 (1993) and Forest Regulation 2051 (1995). Ministry of Forests and Soil Conservation. An official translation of the document in Nepali.

HNCC/MFSC. 2005. Information on the Herbs that have been Prioritized for Cultivation and Research. Herbs and NTFP Coordination Committee, Ministry of Forests and Soil Conservation, Kathmandu, Nepal. A document in Nepali.

Hoberg, G. 2001. Policy Cycles and Policy Regimes: A Framework for Studying Policy Change. In Cashore, B., Hoberg, G., Howlett, M., Rayner, J. and Wilson, J. (eds.) 
In Search of Sustainability: British Columbia Forest Policy in the 1990s. University of British Columbia Press, Vancouver, BC, Canada.

ICIMOD. 2004. Stakeholder Consultation on Planning and Improvement of Corridors between Protected Areas within Kanchenjunga Landscape: overview and outcomes of the planning consultation. International Centre for Integrated Mountain Development, Kathmandu, Nepal. A draft report.

Kanel, K.R. 2002. Policy and Institutional Bottlenecks: Possibilities for NTFP Development in Nepal. In Bhattarai, N. and Karki, M. (eds.) Sharing Local and National Experience in Conservation of Medicinal and aromatic Plants in South Asia. Proceedings of the Workshop held at Pokhara, Nepal, 21-23 January 2001. MAPPA, IDRC and HMG/Nepal.

Kanel, K.R. 2006. Current Status of Community Forestry in Nepal. A report submitted to Regional Community Forestry Training Center for Asia and the Pacific, Bangkok, Thailand.

Karki, M. and Nagpal, A. 2004. Commercilaization of Medicinal, Aromatic and Other NTFPs in Nepal: Self-reflections and Cross Learning. In Bhattarai, N. and Karki, M. (eds.) Local Experience-based National Strategy for Organic Production and Management of MAPs/NTFPs in Nepal. Proceedings on the National Workshop held at Kathmandu, Nepal. IDRC/MAPPA/CCO.

Kellert, S.R., Mehta, J.N., Ebbin, S.A. and Lichrenfeld, L.Y.L. 2000. Community Natural Resource Management: Promise, Rhetoric, and Reality. In Society and Natural Resources 13: 705-715.

Kleinn, C., Laamanen, R. and Malla, S.B. 1996. Integrating the assessment of Non-wood Forest Products into the Forest Inventory of a Large Area: Experiences from Nepal. In Leakey, R.R.B., Temu, A.B., Melnyk, M. and Vantomme, P. (eds.) Domestication and Commercialization of Non-timber Forest Products in Agroforestry Systems. A Proceedings of an International Conference held in Nairobi, Kenya, 19-23 February, 1996. FAO.

Kraft, M.E. and Vig, N.J. 2006. Environmental Policy from the 1970s to the Twenty-First Century. In Vig, N.J. and Kraft, M.E. (eds.) Environmental Policy: New Directions for the Twenty-First Century. Sixth Edition. CQ Press, Washington D.C., USA.

Larsen, O.H., Smith, P.D. and Olsen, C.S. 2005. Nepal's conservation policy options for commercial medicinal plant harvesting: stakeholder views. In Oryx, 39(4): 435441. 
Mahapatra, A.K. and Tewari, D.D. 2005. Importance of non-timber forest products in the economic valuation of dry deciduous forests of India. In Forest Policy and Economics 7: 455-467.

Malla, S.B, Shakya, P.R., Karki, B.R., Mortensen, T.F. and Subedi, N.R. 1999. A Study on Non Timber Forest Products in Bajura District, Vol. I \& II, Care Nepal, Kathmandu, Nepal.

Maraseni, T.N. 2004. Harvesting Techniques and Market Analysis of selected NTFPs in makawanpur District, Nepal. A MS. Thesis. Asian Institute of Technology, School of Environment, Resources and Development. Thailand.

Marshall, E. , Schreckenberg, K. and Newton, A.C. 2006. Commercialization of Non timber Forest Products: Factors influencing success. Lessons learned from Mexico and Bolivia and policy implications for decision-makers. UNEP World Conservation Monitoring Center.

McLain, R.J. and Jones, E.T. 2005. Nontimber Forest Products Management in National Forests in the United States. General Technical Report, Pacific Northwest Research Station, USDA, Forest Service.

MFSC. 2005. A Manual for the Preparation of the Initial Environment Examination Plan and Report. Environment Unit, Ministry of Forests and Soil Conservation, Kathmamdu, Nepal. A document in Nepali.

Neuman, R. and Hirsch, E. 2000. Commercialization of Non-timber Forest Products: Review and Analysis of Research. Center for International Forestry Research, Bogor, Indonesia.

Ojha, H.R. 2000. Current Policy Issues in NTFP Development in Nepal. Asia Network for Small-scale Bio-resources, Kathmandu, Nepal.

Ojha, H. and Bhattari, B. 2003. Learning to Manage a Complex Resource: A Case of NTFP Assessment in Nepal. In International Forestry Review 5(2): 118-127.

O'Laughlin, J. 2004. Policy Analysis Framework for Sustainable Forestry: National Forest Case Study. In Journal of Forestry: 34-41.

Olsen, C.S. and Bhattarai, N. 2005. A Typology of Economic Agents in the Himalayan Plant Trade. In Mountain Research and Development 25(1): 37-43.

Olsen, C.S. and Helles, F. 1997. Medicinal plants, markets, and margins in the Nepal Himalaya: Trouble in paradise. Pp. 363-374. 
Olsen, C.S. and Larsen, H.O. 2003. Alpine Medicinal Plant Trade and Himalayan Mountain Livelihood Strategies. In The Geographical Journal 169(3): 243-254.

Ostrum, E. 2003. How Types of Goods and Property Rights Jointly Affect Collective Action. In Journal of Theoretical politics 15(3): 239-270.

Pandit, B.H. and Thapa, G.B. 2003. A Tragedy of Non-timber Forest Resources in the Mountain Commons of Nepal. In Environmental Conservation 30(3): 283-292.

Peters, C.M. 1996. The Ecology and Management of Non-Timber Forest Resources. World Bank Technical Paper No. 322. The World Bank, Washington D.C.

Pierce, A.R. 1999. The Challenges of Certifying Non-Timber Forest Product. In Journal of Forestry, February 1999. Pp 34-37.

Rawal, R.B. and Shrestha, B. 2006. Yarshagumba Marketing and Related Policy Concerns in Nepal. In Rawal, R. B. and Ghimire, P. (eds.) A Report on the National Workshop on Yarshagumba. HMG, Nepal.

Shanley, P., Pierce, A.R., Laird, S.A. and Guillen, A. 2002. Tapping the Green Market: Certification and Management of Non-timber Forest Products. People and Plant Conservation Series. WWF.

Shanley, P., Pierce, A. and Laird, S. 2005. Beyond Timber: Certification Of Non-Timber Forest Products. Forest Tends, CIFOR and The People Plants.

Sharma, U.R., Malla, K.J. and Uprety, R.K. 2004. Conservation and management efforts of medicinal and aromatic plants in Nepal. In Banko Jankari 14(2).

Shrestha, T.B. 2001. Status Review: National Strategies for Sustainable Development Forestry/Rangeland/Biodiversity. IUCN-The World Conservation Nepal, Kathmandu, Nepal.

Subedi, B.P. 1999. The Non-timber Forest Products Sub-Sector in Nepal: Opportunities and Challenges for Linking the Business with Biodiversity Conservation. A paper presented for the workshop on Natural Resources Management for Enterprise Development in Himalayas, August 19-21, 1999, Nainital, India.

Subedi, B.P. 2006. Linking Plant-based Enterprises and Local Communities to Biodiversity Conservation in Nepal Himalaya. Adroit Publishers, India.

Ticktin, T. 2004. The Ecological Implications of harvesting non-timber forest products. In Journal of Applied Ecology 41: 11-21. 
Ticktin, T., Nantel, P., Ramirez, F. and Johns, T. 2002. Effects Variation on Harvest Limits for Nontimber Forest Species in Mexico. In Conservation Biology 1693): 691-705.

Trauernicht, C., Ticktin, T. and Herrera, G.L. 2006. Cultivation of Non-timber Forest Products Alters Understory Light Availability in a Humid Tropical Forest in Mexico. In Biotropica 38(3): 428-436.

UNDP. 2006. Human Development Report 2006. Beyond scarcity: power poverty and global water crisis. The united Nations Development Programme

Van de Cop, P. and Alam, G. 2006. Designing for Development: Principles and Practices of a Sustainable Medicinal Plant Chain in North India. In Bogers, R.J., Craker, L.E. and Lange, D. (eds.), Medicinal and Aromatic Plants. The Netherlands. Pp.171-180.

Walter, S., Cole, D., Kathe, W., Lovett, P. and Soldan, M.P. 2003. Impact of Certification on the Sustainable Use of NWFP: Lessons-learnt from Three Case Studies. A paper submitted for presentation at the International Conference on Rural Livelihoods, Forests and Biodiversity 19-23 May 2003, Bonn, Germany

Wiersum, F. 1999.Understanding diversity in NTFP management: a neglected issue in NTFP research. In Ros-Tonen, M.A.F. (ed.) Seminar Proceedings: NTFP Research in the Tropenbos Programme: Results and Perspectives Wageningen, 28 January 1999. Pp. 159-160.

Yildiz-Thomas, A. and Karki, M. 2002. Himalayan Medicinal and aromatic Plants: Perspectives for Balancing Use and Conservation. In Yildiz-Thomas, Karki, M., Gurung, K. and parajuli, D. (eds.) Himalayan Medicinal and aromatic Plants, Balancing Use and Conservation. Proceedings of a Regional Workshop. Kathmandu, Nepal. WWF/IDRC. 


\section{APPENDICES}

\section{Appendix 1}

The list of Key Informants

List of Key Informants

\begin{tabular}{|c|c|c|c|}
\hline S.N. & Name & Designation & Organization \\
\hline \multicolumn{4}{|c|}{ Governmental Organizations } \\
\hline 1 & Binod Devkota & Officer & $\begin{array}{l}\text { Department of } \\
\text { Forests }\end{array}$ \\
\hline 2 & Diwakar Dutta Pandey & Deputy Director General & $\begin{array}{l}\text { National Forests } \\
\text { Section, Department } \\
\text { of Forests }\end{array}$ \\
\hline 3 & $\begin{array}{l}\text { Govinda Sharma } \\
\text { Dhakal }\end{array}$ & Quality Control Officer & $\begin{array}{l}\text { Singhadarbar Vaidya } \\
\text { Khana }\end{array}$ \\
\hline 4 & Hari Krishna Sainju & Director General & $\begin{array}{l}\text { Department of Plant } \\
\text { Resources }\end{array}$ \\
\hline 5 & $\begin{array}{l}\text { Jawaharman } \\
\text { Bajracharya } \\
\end{array}$ & Director & $\begin{array}{l}\text { Herbs Production } \\
\text { and Processing } \\
\text { Company Limited }\end{array}$ \\
\hline 6 & Keshav Kanel & Deputy Director General & $\begin{array}{l}\text { Community Forestry } \\
\text { Section, Department } \\
\text { of Forests }\end{array}$ \\
\hline 7 & Pankaj Das & Programm Officer & $\begin{array}{l}\text { HNCC, Ministry of } \\
\text { Forests and Soil } \\
\text { Conservation }\end{array}$ \\
\hline 8 & $\begin{array}{l}\text { Resham Bahadur } \\
\text { Dangi }\end{array}$ & Officer & $\begin{array}{l}\text { Department of } \\
\text { Forests }\end{array}$ \\
\hline \multicolumn{4}{|c|}{ Non governmental Organizations } \\
\hline 1 & Bhes Raj Oli & Officer & WWF-Nepal \\
\hline 2 & Bhisma Subedi & Director & $\begin{array}{l}\text { Asia Network for } \\
\text { (ANSAB) }\end{array}$ \\
\hline 3 & Bhola Bhattari & Member Secretary & FECOFUN \\
\hline 4 & Dil Raj Khanal & Legal Trainer & FECOFUN \\
\hline 5 & Eklabya Sharma & Programme Manager & $\begin{array}{l}\text { Natural Resource } \\
\text { Management } \\
\text { Programme, } \\
\text { ICIMOD }\end{array}$ \\
\hline 6 & Karma Bhutia & NTFP Officer & $\begin{array}{l}\text { The Mountain } \\
\text { Institute (TMI) }\end{array}$ \\
\hline
\end{tabular}




\begin{tabular}{|c|c|c|c|}
\hline 7 & Krishna Prasad Oli & Regional Coordinator & $\begin{array}{l}\text { ABSBIO-EH, } \\
\text { ICIMOD }\end{array}$ \\
\hline 8 & Nawaraj Dahal & Officer & FECOFUN \\
\hline 9 & Nirmal Bhattari & Consultant & $\begin{array}{l}\text { MAPPA CFC } \\
\text { Project, ICIMOD }\end{array}$ \\
\hline 10 & $\begin{array}{l}\text { Raghu Bir Singh } \\
\text { Rawat }\end{array}$ & $\begin{array}{l}\text { Regional Programme } \\
\text { Coordinator }\end{array}$ & MAPPA, ICIMOD \\
\hline 11 & Ram Hari Subedi & Director of Operations & BDS-MaPS \\
\hline \multicolumn{4}{|c|}{ Traders/Harvesters } \\
\hline 1 & Badrinarayan & Head & NPP, Dabur Nepal \\
\hline 2 & Bhabeswar Das & Secretary & NEPHA \\
\hline 3 & Dhruba Raj Bhattari & $\begin{array}{l}\text { Retired Deputy Director } \\
\text { General }\end{array}$ & $\begin{array}{l}\text { Department of } \\
\text { Forests }\end{array}$ \\
\hline 4 & Gunaraj Tahapliya & President & $\begin{array}{l}\text { Community Forestry } \\
\text { User Group }\end{array}$ \\
\hline 5 & Kiran Pandey & Director & $\mathrm{AEC}$ \\
\hline \multicolumn{4}{|c|}{ Researchers } \\
\hline 1 & $\begin{array}{l}\text { Kesar Man } \\
\text { Bajracharya }\end{array}$ & Retired Forester & $\begin{array}{l}\text { Department of } \\
\text { Forests }\end{array}$ \\
\hline 2 & $\begin{array}{l}\text { Krishna Kumar } \\
\text { Shrestha }\end{array}$ & Professor & $\begin{array}{l}\text { Central Department } \\
\text { of Botany, } \\
\text { Tribhuvan } \\
\text { University } \\
\end{array}$ \\
\hline 3 & $\begin{array}{l}\text { Ram Prasad } \\
\text { Chaudhary }\end{array}$ & Professor & $\begin{array}{l}\text { Central Department } \\
\text { of Botany, } \\
\text { Tribhuvan } \\
\text { University }\end{array}$ \\
\hline 4 & Ran Bahadur Rawal & Member & HNCC \\
\hline
\end{tabular}




\section{Appendix 2}

\section{Interview Questions}

\section{General Questions common to all stakeholders}

1. What are the major issues concerning management and trade of NTFPs? Are the policies effective and sufficient to deal with these issues?

2. What is the state of knowledge on production and marketing volumes and ecological impacts of NTFP harvesting?

3. What are the legal and administrative gaps in these policies that may affect implementation?

4. How is the government planning to manage the three plant related policies in coordination with other natural resource policies?

5. Can the policies deal with conservation as well as sustainable use issues simultaneously? How successful are they likely to be in near future?

6. Is the sustainable management of NTFPs feasible in Nepal?

7. What are the challenges for sustainable management of NTFPs in the country, specifically, with the ongoing insurgency and the state of political transition in the country?

8. What are the challenges faced by different stakeholders related to NTFPs use and trade?

9. What are the legal and management hurdles for NTFP domestication? How does it affect different income groups?

10. What are the specific issues regarding the trade of NTFPs in domestic and international markets, respectively? How do the global market trends affect the NTFP sector in Nepal?

11. What are the regional challenges for Nepal for effective implementation of CITES?

12. Do the species listed in the Forest Act and the Rare Plants and Wildlife Trade Control Act need updating? If yes, on what basis and what should be the process?

\section{Governmental organizations}

1. What are the difficulties faced by the government body (respective) in regulating the NTFP sector? (Both in relation to harvester and in relation to middlemen)

2. What are the difficulties faced by the government body (respective) in implementing the policies related to NTFPs?

3. What are the capabilities of its officials? What are the limitations and what are the strategies to deal with it?

4. How are the government bodies coordinating with its various bodies to regulate the NTFP sector?

5. How strictly are the trade on species listed in the Forest Act and CITES regulated?

6. What is their view regarding middlemen in the NTFP sector? 
7. How are royalties set and how often are they reviewed?

8. How are permits issued and on what basis is the harvestable amount calculated?

9. How is the government body going to promote domestication, cultivation and processing of NTFPs? What are the strategies and barriers?

\section{Non-governmental organizations}

1. What are the issues faced by non-government organizations while working with government bodies in the NTFP sector?

2. What are the challenges faced by the NGOs to work with middlemen and harvesters?

3 . How can the policy enhance their capability?

4. What are their expectations from the government, traders and researchers for the success of this policy?

\section{Harvesters and traders}

1. How hard is it to deal with government organizations, what are some of the barriers?

2. What are the gaps in government extension programmes and what are their expectations?

3. What types of support do they expect from the NGO sector?

4. What are the hurdles faced for the following: permits, certification, royalty rates?

5. Are they involved in consultation in taking decisions on the above?

\section{Researchers}

1. What is the level of science required to calculate the harvestable amount of NTFPs from open access forest?

2. What are the ecological implications of harvest of major NTFPs in Nepal?

3. Are there NTFP hotspots in Nepal, where are they located, what are their importance?

4. How can traditional knowledge be incorporated in management of NTFP sector in Nepal? 


\section{Appendix 3}

\section{Plants banned under Forest Act, 1993 and Forest Regulation, 1995 (Nepal Gazette 2001)}

\begin{tabular}{|r|l|l|l|}
\hline \multicolumn{4}{|c|}{ Plants banned for collection, use, sale and distribution, transport and export } \\
\hline SN & Scientific name & Trade name & English name \\
\hline 1 & Dactylorhiza hatagirea & $\begin{array}{l}\text { Panchaule, Hattajadi, } \\
\text { Salampanja }\end{array}$ & Salap \\
\hline 2 & Juglans regia & Okhar bokra & Walnut (bark) \\
\hline \multicolumn{4}{|c|}{ Plants banned for export except processed with permission of Department of Forest } \\
\hline SN & Scientific name & Trade name & English name \\
\hline 1 & Abies spectabilis & Gobresalla, Talispatra, & $\begin{array}{l}\text { Himalayan fir, Silver } \\
\text { fir }\end{array}$ \\
\hline 2 & $\begin{array}{l}\text { Cinnamomum } \\
\text { glaucescens }\end{array}$ & Sugandhakokila, Malagedi & Nepal sassafras \\
\hline 3 & Cordyceps sinensis & Yarchagumba, Jeevanbuti & $\begin{array}{l}\text { Cordyceps, } \\
\text { Caterpillar fungus }\end{array}$ \\
\hline 4 & Nardostachys grandiflora & Jatamansi, Bhulte, Balchhar & Spikenard \\
\hline 5 & Parmelia nepalensis & Jhyau & Lichen \\
\hline 6 & Rauvolfia serpentina & Sarpagandha & Serpentine \\
\hline 7 & Rock exudate & Silajit & Rock exudate \\
\hline 8 & Taxus wallichiana & Loth sallo, Talispatra & Himalayan yew \\
\hline 9 & Valeriana jatamansii & Sugandhawal, Tagar & Indian Valerian \\
\hline \multicolumn{4}{|c|}{ Trees banned for transport, export and felling for commercial purpose } \\
\hline 2 & Bombax ceiba & Shade name & English name \\
\hline 3 & Dalbergia latifolia & Satisal & Cutch tree \\
\hline 4 & Juglans regia & Okhar & Rose Wood \\
\hline SN & Scientific name & Acacia catechu & Walnut \\
\hline 2 & Sotton tree \\
\hline
\end{tabular}




\begin{tabular}{|r|l|l|l|}
\hline 5 & Michelia champaca & & Magnolia \\
\hline 6 & Pterocarpus marsupium & Bijayasaal & Indian Kino Tree \\
\hline 7 & Shorea robusta & Sal & Sal \\
\hline \multicolumn{3}{|c|}{ availability of the sepecies by DoF } \\
\hline \multicolumn{3}{|c|}{ Plant banned for export except recommendation of DPR alid species and } \\
\hline 1 & $\begin{array}{l}\text { Picrorhiza } \\
\text { scrophulariiflora }\end{array}$ & Katuki, Kutaki & Picrorhiza \\
\hline & & & \\
\hline
\end{tabular}




\section{Plants in Nepal listed under the Rare (Endangered) Wildlife and Plants Trade Control Act, 2000 (draft)}

\begin{tabular}{|r|l|l|l|l|}
\hline SN & Scientific name & Trade name & English name & $\begin{array}{l}\text { CITES } \\
\text { Categories }\end{array}$ \\
\hline 1 & Ceropegia sp. & & Milkweeds & Appendix II \\
\hline 2 & Cyatheaceae & & Tree ferns & Appendix II \\
\hline 3 & Cycadaceae & & Cycas & Appendix II \\
\hline 4 & Cycas pectinata & & Himalayan cycas & Appendix III \\
\hline 5 & Dioscorea deltoidea & Bantarul, Bhyakur & Deltoid yam & Appendix II \\
\hline 6 & Gnetum montanum & & Gnetum & Appendix III \\
\hline 7 & Meconopsis regia & & $\begin{array}{l}\text { Himalayan } \\
\text { yellow poppy }\end{array}$ & Appendix III \\
\hline 8 & $\begin{array}{l}\text { Neopicrorhiza } \\
\text { scrophulariiflora }\end{array}$ & Katuki, Kutaki & Picrorhiza & Appendix II \\
\hline 9 & Orchid spp. & Sungava & Orchids & Appendix II \\
\hline 10 & $\begin{array}{l}\text { Podophyllum } \\
\text { hexandrum }\end{array}$ & $\begin{array}{l}\text { Laghupatra, } \\
\text { Hatkaudo, Papra }\end{array}$ & Podophyllum & Appendix II \\
\hline 11 & Rauvolfia serpentine & Sarpagandha & Serpentine & Appendix II \\
\hline 12 & Saussurea costus & Kuth, Kutha & Costus & Appendix I \\
\hline 13 & Talauma hodgsonii & Chap & Magnolia & Appendix III \\
\hline 14 & Taxus wallichiana & $\begin{array}{l}\text { Loth sallo, } \\
\text { Talispatra }\end{array}$ & Himalayan yew & Appendix II \\
\hline 15 & Tetracentron sinense & Bharikote & Tetracentron & Appendix III \\
\hline
\end{tabular}




\section{Royalty rates}

(Nepal gazette, 2006)

\begin{tabular}{|c|c|c|c|}
\hline \multicolumn{4}{|c|}{ Root and Rhizome Harvesting Species } \\
\hline SN & Nepali Name & Scientific Name & $\begin{array}{c}\text { Royalty } \\
\text { (NRs./kg.) }\end{array}$ \\
\hline 1 & Atis & Aconitum heterophyllum & 15 \\
\hline 2 & Asarephool & - & 8 \\
\hline 3 & Indreni & $\begin{array}{l}\text { Citrullus colosynthis, Trichosanthes } \\
\text { palmate }\end{array}$ & 10 \\
\hline 4 & Unyau & Dryopteris filix-mas & 8 \\
\hline 5 & Kachur & Curcuma zedoaria & 5 \\
\hline 6 & Kakoli & Fritillaria cirrhosa & 5 \\
\hline 7 & Kamraj & Helminthostachys zeylanica & 6 \\
\hline 8 & Kalomusali & Curculigo orchioides & 6 \\
\hline 9 & Kukurtarul, Bantarul & Dioscorea spp. & 5 \\
\hline 10 & Kutki & Picrorhiza scrophulariiflora & 10 \\
\hline 11 & Kurilo, Satawari & Asparagus spp. & 5 \\
\hline 12 & Khaskhas & Vetiveria zizaniodes & 2 \\
\hline 13 & Gamdol & Brachycorythis obcordata & 10 \\
\hline 14 & Gujargano & Stephania spp., Cissampelos pareira & 5 \\
\hline 15 & $\begin{array}{l}\text { Gurjo, Chinilahara, } \\
\text { Guduchi }\end{array}$ & Tinospora sinensis, T. cordifolia & 2 \\
\hline 16 & Jatamansi & Nardostachys grandiflora & 15 \\
\hline 17 & Jamanemandro, Daruhaldi & Mahonia napaulensis & 2 \\
\hline 18 & Tukiphool & Taraxacum officinale & 5 \\
\hline 19 & \begin{tabular}{|l|} 
Nagarmothe, Mothe, \\
Kasur
\end{tabular} & Cyperus spp. & 5 \\
\hline 20 & Nirmasi & Delphinium denudatum & 50 \\
\hline 21 & Padamchal & Rheum australe & 5 \\
\hline 22 & Pakhanbed/Pasanved & Bergenia ciliate/ B. ligulata & 2 \\
\hline 23 & Panchaule & Dactylorhiza hatagirea & $500 /$ piece \\
\hline
\end{tabular}




\begin{tabular}{|c|c|c|c|}
\hline 24 & Pipala, Pipli, Murjhang & Piper longum & 10 \\
\hline 25 & Bajradanti & Potentilla fulgens, Murrya paniculata & 2 \\
\hline 26 & Banlasun & Allium wallichii & 10 \\
\hline 27 & Bilaune & Maesa chisia & 5 \\
\hline 28 & Bish & Aconitum spicatum & 7 \\
\hline 29 & Bishafej & Polypodium vulgare & 5 \\
\hline 30 & Bishama & Aconitum palmatum & 10 \\
\hline 31 & Bojho & Acorus calamus & 3 \\
\hline 32 & Bhutkesh & Selinum tenuifolium & 4 \\
\hline 33 & Mamira & Coptis teeta & 70 \\
\hline 34 & Laghupatra & Podophyllum hexandrum & 5 \\
\hline 35 & Satuwa & Paris polyphylla & 10 \\
\hline 36 & \begin{tabular}{|l|} 
Sarpagandha, \\
Chandmaruwa \\
\end{tabular} & Rauwolfia serpentine & 50 \\
\hline 37 & Sisnu & Urtica dioica & 2 \\
\hline 38 & Sugandhawal & Valeriana jatamansi & 15 \\
\hline 39 & Setakchini, Kukurdaino & Smilax spp. & 5 \\
\hline \multicolumn{4}{|c|}{ Bark Harvesting Species } \\
\hline $\mathbf{S N}$ & Nepali Name & Scientific Name & $\begin{array}{c}\text { Royalty } \\
\text { (NRs./kg.) }\end{array}$ \\
\hline 1 & Okhar & Juglans regia var. kamaonia & 100 \\
\hline 2 & Angeri & Lyonia ovalifolia & 5 \\
\hline 3 & Kaphal & Myrica esculenta & 100 \\
\hline 4 & Kalchuri & Litsea glutinosa & 5 \\
\hline 5 & Chutro & Berberis sp. & 8 \\
\hline 6 & Chhatiwan & Alstonia scholaris & 5 \\
\hline 7 & Jamanemandro & Mahonia napaulensis & 2 \\
\hline 8 & Tatelo, Totala & Oroxylum indicum & 5 \\
\hline 9 & Dar & Boehmeria rugulosa & 5 \\
\hline 10 & Dhupi & Juniperus spp. & 25 \\
\hline 11 & Nepali dalchini, Sinkauli & Cinnamomum tamala & 10 \\
\hline
\end{tabular}




\begin{tabular}{|c|c|c|c|}
\hline 12 & Palans & Butea monosperma & 20 \\
\hline 13 & Pawan, Kaulo & Persea spp. & 5 \\
\hline 14 & Paiyun & Prunus cerasoides & 10 \\
\hline 15 & Bakaino & Melia azedarach & 2 \\
\hline 16 & Bhojpatra & Betula utilis & 15 \\
\hline 17 & Bhorla & Bauhinia vahlii & 1 \\
\hline \multicolumn{4}{|c|}{ Leaf Bearing Species } \\
\hline SN & Nepali Name & Scientific Name & $\begin{array}{c}\text { Royalty } \\
\text { (NRs./kg.) }\end{array}$ \\
\hline 1 & Asuro/Adusa & Adhatoda vasica & 1 \\
\hline 2 & Unyu & Dryopteris filix-mas & 1 \\
\hline 3 & Kumkum & Didymocarpus leucocalyx & 2 \\
\hline 4 & Chumlani & Skimmia laureola & 25 \\
\hline 5 & Jagar, Jigar & - & 2 \\
\hline 6 & Tokla & - & 1 \\
\hline 7 & Thinguresalla & Tsuga dumosa & 2 \\
\hline 8 & Talispatra & Abies spectabilis & 5 \\
\hline 9 & Titepati & Artemisia spp. & 50 \\
\hline 10 & Tejpat & Cinnamomum tamala & 2 \\
\hline 11 & Tendupat & Diospyros tomentosa & 2 \\
\hline 12 & Dudhelahara & - & 1 \\
\hline 13 & $\begin{array}{l}\text { Dhasingre, Machhino, } \\
\text { Patpate }\end{array}$ & Gaultheria fragrantissima & 25 \\
\hline 14 & Dhupi & Juniperus spp. & 2 \\
\hline 15 & Nagbeli & Lycopodium clavatum & 5 \\
\hline 16 & Nundhiki & Osyris spp. & 1 \\
\hline 17 & Bhalayo & Semecarpus anacardium & 1 \\
\hline 18 & Bhorla & Bauhinia vahlii & 50 \\
\hline 19 & Masala & Eucalyptus spp. & 10 \\
\hline 20 & Malata & Macaranga spp. & 50 \\
\hline 21 & Lemongrass & Cymbopogon flexuosus & 50 \\
\hline
\end{tabular}




\begin{tabular}{|c|c|c|c|}
\hline 22 & $\begin{array}{l}\text { Lothsalla ko } \\
\text { Pat/Danth/Sinka }\end{array}$ & Taxus baccata & 25 \\
\hline 23 & Sal & Shorea robusta & 10 \\
\hline 24 & Silaginella & Selaginella spp. & 1 \\
\hline 25 & Sunpati & Rhododendron anthopogon & 3 \\
\hline 26 & Hinguwa & Camellia kissi & 50 \\
\hline \multicolumn{4}{|c|}{ Flower Harvesting Species } \\
\hline SN & Nepali Name & Scientific Name & $\begin{array}{c}\text { Royalty } \\
\text { (NRs. per } \\
\text { kg.) }\end{array}$ \\
\hline 1 & Asuro, Adusa & Adhatoda vasica & 1 \\
\hline 2 & Koiralo/Kachanar & Bauhinia variegate & 0.5 \\
\hline 3 & Gurans, Chimaal, Sunpati & Rhododendron spp. & 2 \\
\hline 4 & Tukiphool & Taraxacum officinale & 5 \\
\hline 5 & Dhanyero & Woodfordia fruticosa & 1 \\
\hline 6 & Nageswor, Nareswor & Mesua ferrea & 5 \\
\hline 7 & Padampuskar & Iris nepalensis & 3 \\
\hline 8 & Buki & Gnaphalium spp./Anaphalis spp. & 1 \\
\hline 9 & Mauwa (Pahadi) & Englehardtia spicata & 2 \\
\hline 10 & Rukhakamal & Magnolia grandiflora & 25 \\
\hline 11 & Simalko Phool & Bombax ceiba & 3 \\
\hline 12 & Annya Phool & - & 1 \\
\hline 13 & Aanka ko Bhuwa & Calotropis gigantean & 4 \\
\hline 14 & Simal ko Bhuwa & Bombax ceiba & 4 \\
\hline \multicolumn{4}{|c|}{ Fruit and Seed Harvesting Species } \\
\hline SN & Nepali Name & Scientific Name & $\begin{array}{l}\text { Royalty } \\
\text { (NRs./kg.) }\end{array}$ \\
\hline 1 & Ander & Ricinus communis & 2 \\
\hline 2 & Amala & $\begin{array}{l}\text { Phyllanthus emblica (Emblica } \\
\text { officinalis) }\end{array}$ & 1 \\
\hline 3 & Asna, Saj & Terminalia tomentosa & 2 \\
\hline 4 & Indrajau, Madhisekhirro & Holarrhena antidysenterica & 1 \\
\hline 5 & Indrayani & $\begin{array}{l}\text { Citrullus colosynthis, Trichosanthes } \\
\text { palmate }\end{array}$ & 8 \\
\hline
\end{tabular}




\begin{tabular}{|c|c|c|c|}
\hline 6 & Utis & Alnus nepalensis & 50 \\
\hline 7 & Okhar & Juglans regia & 5 \\
\hline 8 & Kantakari & Solanum xanthocarpum & 1 \\
\hline 9 & Kaayiyo Phal & Pavetta indica & 2 \\
\hline 10 & Kauso & Mucuna prurita & 2 \\
\hline 11 & Kusum & Schleichera oleosa & 2 \\
\hline 12 & Koiralo/Kachanar & Bauhinia variegate & 1 \\
\hline 13 & Khotesallko Biu & Pinus roxburghii & 200 \\
\hline 14 & Champawati, Chanp & Michelia champaca & 500 \\
\hline 15 & Chiuri & Bassia butyracea & 3 \\
\hline 16 & Chilauneko Geda & Schima wallichii & 25 \\
\hline 17 & Jangali Jira & Centratherum anthelminticum & 5 \\
\hline 18 & Jangali Jwano & - & 5 \\
\hline 19 & Jamun & Syzygium cumini & 1 \\
\hline 20 & Timur & Zanthoxylum armatum & 8 \\
\hline 21 & Dhalekatus & Castanopsis indica & 1 \\
\hline 22 & Tigedi & - & 5 \\
\hline 23 & Debdar & Cedrus deodara & 100 \\
\hline 24 & Dhaturo & Datura spp. & 2 \\
\hline 25 & Dhupi ko Geda & Juniperus spp. & 3 \\
\hline 26 & Nagbeli ko Paudar & Lycopodium clavatum & 20 \\
\hline 27 & Nageswor, Nareswor & Mesua ferrea & 5 \\
\hline 28 & Palans & Butea monosperma & 5 \\
\hline 29 & Pangra & Entada phaseoloides, Aesculus indica & 5 \\
\hline 30 & Pani Amala & Nephrolepis cordifolia & 1 \\
\hline 31 & Pipla, Pipali, Murjhang & Piper longum & 10 \\
\hline 32 & Bakaino & Melia azedarach & 50 \\
\hline 33 & Ban Karela & Herpetospermum pendunculosum & 1 \\
\hline 34 & Bayar & Ziziphus mauritiana & 2 \\
\hline 35 & Barro & Terminalia bellirica & 1 \\
\hline
\end{tabular}




\begin{tabular}{|r|l|l|c|}
\hline 36 & Budhani/Jhyau & Lichen & 3 \\
\hline 37 & Bet & Calamus tenius & 5 \\
\hline 38 & Bel & Aegle marmelos & 2 \\
\hline 39 & Bhadracha & - & 8 \\
\hline 40 & Bhalayo & Semecarpus anacardium & 2 \\
\hline 41 & Bhujetro & Butea minor & 5 \\
\hline 42 & Mauwa (Terai) & Bassia latifolia & 3 \\
\hline 43 & Mauwa (Pahadi) & Engelhardtia spicata & 3 \\
\hline 44 & Ratigedi, Lalgedi & Abrus precatorius & 5 \\
\hline 45 & Rajbriksha & Cassia fistula & 2 \\
\hline 46 & Ramphal & Annona reticulate & 2 \\
\hline 47 & Ritha & Sapindus mukorossi & 2 \\
\hline 48 & Rukhakamalko Phal & Magnolia grandiflora & 25 \\
\hline 49 & Rudrakchha & Elaeocarpus sphaericus & 5 \\
\hline 50 & Rohini, Sindure & Mallotus philippinensis & 5 \\
\hline 51 & Lapsi & Choerospondias axillaris & 2 \\
\hline 52 & Sagiwan & Jatropha curcas & 2 \\
\hline 53 & Sallako Simta & Cones of Conifers & 2 \\
\hline 54 & Sal ko Biu & Shorea robusta & 2 \\
\hline 55 & Sikakai, Rasulla & Acacia concinna & 2 \\
\hline 56 & Simalko Phal & Bombax ceiba & 2 \\
\hline 57 & Siltimur & Lindera neesiana & 2 \\
\hline 58 & Sitaphal & Annona squamosa & 2 \\
\hline 59 & Sugandhakokila, & Cinnamomum glaucescens & 2 \\
\hline 60 & Hadchur & Viscum album, V. articulatum & 2 \\
\hline 61 & Harro & Terminalia chebula & 2 \\
\hline
\end{tabular}




\begin{tabular}{|c|c|c|c|}
\hline 2 & Eklebir & Lobelia pyramidalis & 5 \\
\hline 3 & Gurjolahara & Tinospora sinensis, $T$. cordifolia & 2 \\
\hline 4 & Ghodtapre & Centella asiatica & 0.5 \\
\hline 5 & Chiraito & Swertia chirayita, Swertia spp. & 15 \\
\hline 6 & Titepate & Artemesia spp. & 0.5 \\
\hline 7 & Dronapuspi & Leucas cephalotus & 5 \\
\hline 8 & Punarnawa & Boerhavia diffusa & 8 \\
\hline 9 & Bhringraj & Eclipta prostrate & 0.5 \\
\hline 10 & Majitho & Rubia manjith & 3 \\
\hline 11 & $\begin{array}{l}\text { Yarsagumba, } \\
\text { Yarchaghumbu }\end{array}$ & Cordyceps sinensis, C. spp. & 10,000 \\
\hline 12 & Somlata & Ephedra gerardiana & 5 \\
\hline \multicolumn{4}{|c|}{ (Plant extracts and others) } \\
\hline SN & Nepali Name & Scientific Name & $\begin{array}{c}\text { Royalty } \\
\text { (NRs./kg.) }\end{array}$ \\
\hline 1 & Kakarsingi & Insect gall on Pistacia integerrima & 10 \\
\hline 2 & Gokuldhup & - & 5 \\
\hline 3 & Main & Bee wax & 5 \\
\hline 4 & Maha & Bee Honey & 10 \\
\hline 5 & Laha & Lac gum & 40 \\
\hline 6 & Silagit & Rock exudates & 50 \\
\hline 7 & Salla ko khoto & Pinus roxburghii & 3 \\
\hline 8 & Sal dhup & Shorea robusta & 5 \\
\hline \multicolumn{4}{|c|}{ Others } \\
\hline SN & Nepali Name & Scientific Name & $\begin{array}{c}\text { Royalty } \\
\text { (NRs./kg.) }\end{array}$ \\
\hline 1 & Anantamul & Hemidesmus indicus & 10 \\
\hline 2 & Aamphi & Pyrularis edulis & 1 \\
\hline 3 & Karbela & - & 15 \\
\hline 4 & $\begin{array}{l}\text { Karajchulthi/Chulthi } \\
\text { Aamilo }\end{array}$ & Rheum australe petiole & 3 \\
\hline 5 & Kaladana & Eulophia spp. & 5 \\
\hline 6 & Guchhi Chayu & Morchella spp. & 200 \\
\hline
\end{tabular}




\begin{tabular}{|r|l|l|c|}
\hline 7 & Chabo & Piper chaba & 5 \\
\hline 8 & Jhyau & Parmelia spp./Lichen & 15 \\
\hline 9 & Bidarikanda & Pueraria phaseoloides & 2 \\
\hline 10 & Sadharan Chayu & Wild mushroom & 5 \\
\hline 11 & Halhale & Rumex nepalensis & 3 \\
\hline
\end{tabular}

US \$ $1=$ NRs. 68.40 (May 16, 2007) 


\title{
Appendix 6
}

\section{Herbs and NTFP Development Policy, 2004}

\author{
Government of Nepal \\ Ministry of Forests and Soil Conservation \\ Herbs and NTFP Development Coordination Committee \\ Thapathali. Kathmandu, Nepal
}

(Unofficial translation)

\section{Background}

The biological diversity found in Nepal due to the geographical and environmental diversity has been beneficial. Nepal is known in the World for rich biodiversity due to the presence of various types of ecosystems. Thus there is an opportunity as well as challenge of economic development of Nepalese people along with social mobilization through sustainable management and use of these resources.

It has been estimated that there are 118 types of ecosystems in Nepal. A total of 10091 plants including 5884 flowering plants have already been identified in these ecosystems. About 700 species have been found to have medicinal value. Out of these, 238 species have already been tested for their chemical contents.

It is known that herbs and non-timber forest products (NTFPs) are very important for human medicine. Further, the use of aromatic plants in cosmetic products is also increasing giving a possibility for economic benefits. Thus for the scientific and commercial scale cultivation of herbs, increasing production of agriculturally uncultivable and marginal lands, helping in conservation of environment and helping in the economically poor and marginalized families would be inevitable.

Nepal is a member of the WTO and there are possibilities and challenges for biodiversity conservation and sustainable use. There is a challenge to establish legal rights over species that are rare and important for human medicine. At the same time there is extreme opportunity of getting economic benefits as well.

Nepal has not been able to gain much benefit from herbs and NTFPs because the cultivation, collection, use and marketing is done in a traditional manner. There is a need for value addition through processing and packaging of species that are in high demand in international markets to get maximum benefit within Nepal.

The tenth five year plan emphasizes employment generation and export promotion; further, poverty alleviation by promoting under privileged women and groups of society 
to get benefits from production, processing and marketing of herbs and NTFPs that are important source of income are also inherent. However, the forestry policies do not have a strategy for conservation and sustainable use of herbs and NTFPs, thus a separate policy was required.

For the overall development of herbs and the NTFP sector, the organizations that do identification, research and technology development on plant resources in Nepal have a major role to play.

Nepal has implemented market liberalization and commercial competitive strategies which should be applied in production, collection, processing and marketing of herbs and NTFPs. Thus there is a need for the development of policy for the promotion of this sector.

To date, production and marketing of herbs and NTFPs in Nepal is done in an unorganized way. To get the maximum benefit, there is a need for development of this sector in an organized way, and to develop and strengthen forward and backward linkages. For this, the involvement of farmers, small, medium and large scale entrepreneurs, private sector, cooperatives through the facilitative role of government is very important. Thus for the development and promotion of cultivation of NTFPs and help in economic development, government, non-government and the private sector's roles should be defined. Further to commercialize herbs and NTFPs and help in economic and social mobilization of Nepal and its people, the Herbs and NTFPs Development Policy, 2004 has been adopted.

\section{Long-term Vision}

The long term vision of this policy is to help the economy through conservation and sustainable management of high value NTFPs and make Nepal well-known worldwide as a source of Herbs and NTFPs by 2020.

\section{Objectives:}

(vii) Conservation and management of natural sources of herbs and NTFPs based on the concept of sustainable development so as to help in the regeneration of species and obtain maximum economic and environmental benefits through sustainable harvest and management, processing, production and marketing processes.

(viii) Cultivate important NTFPs for commerce so as to help in ex-situ conservation of species as well as help in the national economy and employment

(ix) Promote primary processing and value addition of herbs and NTFPs at the local level so as to increase employment and income in remote and rural areas; and increase participation of local private sectors so as to enhance local economies through value addition in collection and marketing centers.

(x) Commercialize herbs and NTFPs and make it competitive by providing capital, infrastructure, technical knowledge, skill and marketing management so as to help in poverty alleviation and improve livelihoods of local people 
(xi) Ensure the participation of disadvantaged, poor and women in communities in the collection, processing, production and marketing of herbs and NTFPs and promote gender and social mobilization through natural resource management.

(xii) Promote the herbs and NTFP sector to be competitive in the global market so as to help the national economy.

\section{Strategy}

\section{Conservation and management focusing on the concept of sustainable development}

a. Management would be initiated by inventory of natural source of herbs and NTFPs and development of criteria for good harvesting practices. Management will focus on use which takes into account the conservation and natural regeneration in natural sources.

b. The Herbs and NTFP coordination committee will play a major role in monitoring and evaluation of policies and programmes in herbs and NTFP sector.

c. Conservation of endangered species of herbs and NTFPS would be done through both in-situ and ex-situ management processes.

d. Find national and global market demands of herbs and NTFPs and ensure constant supplies through cultivation or supply through natural forests.

e. Study the availability of herbs and NTFPs and declare certain areas as NTFP zones; involve local participation in development, management and conservation programmes of species in such areas.

f. Develop the competitiveness in the collection of herbs and NTFPs available in the districts and focus on creating maximum benefit to local inhabitants and entrepreneurs.

g. Develop and implement separate short term and long term plans for the overall development of herbs and NTFPs.

\section{Promote the participation of people}

h. Natural sources may not be enough for the commercialization of herbs and NTFPs, thus cultivation in leasehold forests, community forests and other private lands and by groups would be promoted. Women who are under the poverty line would be given priority and ensure maximum benefit to them through participation. Buffer zone groups and farmer groups would be involved in the participation process.

i. Marketing networks among harvesters, collectors and sellers of herbs and NTFPs would be developed for the management of the sector. The private sector and cooperatives would be promoted for marketing and export. 
j. The value addition at the local level of herbs and NTFPs, which can be processed within the country, would be done through promotion of government, private and related local organizations in this sector. Infrastructure will be developed for these sources.

\section{Simplify the certification and taxation process}

k. The certification and taxation process would be simplified for the herbs and NTFPs that are cultivated privately.

1. The marketing of herbs and NTFP species that are cultivated on private lands either in processed or unprocessed form would be made easy.

m. Forest certification processes would be promoted for the herbs and NTFPs that are collected based on sustainable management. In addition organic farming certification processes would be initiated.

n. The present labs would be strengthened for the characterization, mapping and identification of genetic diversity of plants and the labs would be developed for biotechnological study and development.

o. The royalty rates of the herbs and NTFPs that are collected from forests would be based on local market prices used by collectors. The royalty rate would be updated every five years.

\section{Make research and development accessible to communities}

p. The herbs and NTFPs that have prospects of commercialization will be identified, inventoried and cultivation techniques developed. The research would be disseminated to forestry and farmer groups and to those who are involved in soil conservation programmes.

q. The research would be initiated to identify medicinal and aromatic oils found in plants. The chemicals that have been already researched would be promoted for processing and isolation to help in commercialization.

r. To get benefits from the plants found in the country, the scope for bio prospecting would be looked into with help and contacts with international organizations. With the goal toward maximum benefits for Nepal if there is a possibility of marketing of genetic resource or plants in international markets.

s. The characteristics and uses of valuable herbs of Nepal would be promoted at the international level.

t. Various organizations that are working on research and development of herbs and NTFPs would be promoted so as to avoid overlap of their work. 
5. Facilitate skill development and commercialization process through awareness

u. Awareness on collection, management and cultivation techniques on herbs and NTFPs would be promoted and opportunities for skill development would be provided.

v. The government would give special consideration to any person or group who are interested in cultivation, processing and marketing of herbs.

\section{Work-plans}

1. Integration and improvement of policies for the government to continue to play the role of facilitator, catalyst and regulator in the collection, production, cultivation and processing of herbs and NTFPs by the private sector and through cooperatives.

2. The cooperatives formation process would be promoted in Nepal to get benefits to groups through production and development of herbs and NTFPs. Loan processing would be facilitated through agricultural development banks or other organizations for cultivation, collection, processing and marketing of herbs and NTFPs by groups, cooperatives and the private sector.

3. The process of value addition would be promoted through scientific methods in storing, processing, packaging and extraction of chemicals of herbs and NTFPs found in Nepal. For this, development of small scale enterprises at the local level would be given priority and the government will give required technical and financial support.

4. The process of registration for cultivation of herbs and NTFPs on private lands in district forest offices would be facilitated.

5. The process of documentation of the herbs and NTFPs found in Nepal would be continued through various studies. The collection and marketing based on annual natural production statistics at sustainable levels would be promoted by doing inventory of such resources.

6. The herbs and NTFP sector would be included in management plans of leasehold forests and community forests to promote cultivation on such forests. User groups would be provided with required knowledge, skills and financial support.

7. The cultivation and collection of herbs and NTFPs would be promoted in government managed forests through the private sector and cooperatives.

8. Genetic resource policies would be formulated and implemented for equitable sharing of benefits from genetic resources and genetic materials that are found in abundance in Nepal. Policies would be developed for the preservation of traditional knowledge on NTFPs and through documentation of such knowledge.

9. Ayurvedic and allopathic medicine would be promoted at the national level. For this, the continuity of raw materials ie., herbs and NTFPs for such factories would be ensured through collection and cultivation of relevant species. 
10. International funding and technology could also be promoted for modern and large scale enterprises at the national level. Cottage industries would be promoted based on traditional knowledge and national funding. The benefits of producers, collectors and entrepreneurs would be ensured in such processes.

11. Clarify the role of district level small and cottage industries offices to establish, manage and promote herbs and NTFPs based small enterprises.

12. Declare certain areas as "NTFP zone" based on availability of herbs and NTFPs; involve local participation in development, management and conservation of NTFPs and initiate income generating activities.

13. Environmental policies and plans would be reviewed so as to help facilitate commercialization of herbs and NTFPs.

14. "NTFP fairs" would be organized on a regular basis with the help of Market promotion centers, Nepal Federation of Chambers of Commerce and international level diplomatic offices to get access into international markets for NTFPs found in Nepal. Such fairs would be organized inside the country at the district level as well. Display centers for NTFPs would also be developed.

15. Management and capacity building of government and non government organizations involved actively in herbs and NTFP development sector. Quarantine mechanisms would be developed to help in export promotion.

16. To help in herbs and NTFP production and commercialization the capacity of local organizations would be increased.

17. Marketing information networks would be developed to give information on national and international markets to producers, collectors, processors and exporters. National and regional level market information centers would be established.

18. Development of organizational integration for herbs and NTFP production, processing and marketing into small farmer programmes, women's development programmes and rural women's credit programmes for small enterprises. Agricultural loans for poor and marginalized groups would be channeled through local development funds and poverty alleviation funds.

19. Marginal and un-used lands which are unsuitable for agriculture would be promoted for the cultivation of herbs and NTFPs by poor, landless and marginalized families in groups.

20. Increase the awareness of people who are below the poverty line on the collection and cultivation of herbs and NTFPs through training, fairs and information exchanges. Rural women would be given priority.

21. Maintain minimum standards of herbs and NTFPs to promote marketing to third countries. Labs at the national level would be developed to certify material safety, product analysis, product certification of herbs and NTFPs produced in Nepal and this would be expanded to regional levels over time. 
22. The standards for laboratories would be increased for the identification, and testing of herbs and NTFPs and for quality control of the medicines and other products.

23. The herbs and NTFPs that are imported as raw materials would have to meet minimum quality standards.

24. Integrate technical and business related courses in universities and government technical schools to generate manpower on production, collection and marketing of herbs and NTFPs. The topic of herbs and NTFPs would be included in all the natural resource management courses.

25. Gradually develop companies that are under the government on cultivation, collection, production, processing and marketing of herbs and NTFPs according to market demand.

26. The commercial cultivation of relevant herbs and NTFPs in relevant seasons and localities of the country would be promoting taking into consideration the variability of geography and environment. Cultivation techniques of commercially important species would be handed over to the farmers.

27. Make relevant changes in traditional techniques of production, collection, use and management of herbs and NTFPs and promote and develop modern technology.

28. Encourage farmers to plant NTFPs with other agricultural crops and provide them with the required technical knowledge. 


\section{Appendix 7}

\section{Herbs and NTFP Coordination Council}

Chairman:

Minister of Forests and Soil Conservation

Vice Chairman:

Deputy Minister of Forests and Soil Conservation

Members:

Hon. Member, National Planning Commission (Forestry sector related)

Secretary, Ministry of Forests and Soil Conservation

Director General, Department of Agriculture

Representative of Ministry of Local Development

Representative of Royal Nepal Academy of Science and Technology

Director General, Department of Forests,

Director General, Department of Ayurveda

Mr. Rana Bahadur Rawal (Expert)

ANSAB

Mr. Pradeep Jung Pandey (FNCCI)

Member Secretary:

Director General, Department of Plant Resources 


\section{Appendix 8}

\section{Medicinal Plants Prioritized for Research and Development by the Department of Plant Resources}

\begin{tabular}{|l|l|l|}
\hline SN & Scientific Name & Nepali name \\
\hline 1 & Aconitum heterophyllum & Atish \\
\hline 2 & Aconitum spicatum & Bish \\
\hline 3 & Acorus calamus & Bojho \\
\hline 4 & Asparagus racemosus & Satawari \\
\hline 5 & Azadirachta indica & Neem \\
\hline 6 & Bergenia ciliate & Pakhanbed \\
\hline 7 & Cinnamomum glaucescens & Sugandhakokila \\
\hline 8 & Cinnamomum tamala & Tejpat \\
\hline 10 & Dactylorhiza hatagirea & Pancaule \\
\hline 11 & Dioscorea deltoidea & Bhyakur \\
\hline 12 & Gaultheria fragrantissima & Dhasingare \\
\hline 13 & Juglans regia & Okhar \\
\hline 14 & Lichens & Jhayu \\
\hline 15 & Morchella sp. & Guchhi chayu \\
\hline 16 & Nardostachys grandiflora & Jatamansi \\
\hline 17 & Neopicrorhiza scrophularifolia & Kutki \\
\hline 18 & Phyllanthus emblica & Amala \\
\hline 19 & Piper longum & Pipla \\
\hline 20 & Podophyllum hexandrum & Laghupatra \\
\hline 21 & Rauvolfia serpentine & Sarpagandha \\
\hline 22 & Rheum australe & Padamchal \\
\hline 23 & Rubia manjith & Majitho \\
\hline 24 & Sapindus mukorossi & Ritha \\
\hline 25 & Swertia chirayita & Chiraito \\
\hline 26 & Tagetes minuta & Jangali saypatri \\
\hline 27 & Taxus baccata & Lauth salla \\
\hline 28 & Tinospora sinensis & Gurjo \\
\hline 29 & Valeriana jatamansii & Sugandhabal \\
\hline 30 & Zanthoxylum armatum & Timur \\
\hline & & \\
\hline
\end{tabular}

